\title{
Emballonurid bats from Colombia: Annotated checklist, distribution, and biogeography
}

\author{
Hugo Mantilla-Meluk ${ }^{*}$, Héctor E. Ramírez-Chaves ${ }^{2}$, \\ Alex M. Jiménez-Ortega ${ }^{3}$ y Miguel E. Rodríguez-Posada ${ }^{4}$
}

Introduction: Genetic data hypothetically place the origin of the most recent common ancestor of the subfamily Emballonurinae in Africa, suggesting a dispersal event from Africa to South America during the Oligocene (30 Ma), and a subsequent allopatric radiation in the New World. Emballonurid genera exist in Central America where, to date, only one event of diversification has been documented for Balantiopteryx before the completion of the Isthmus of Panama land connection in the Pliocene.

Methods: Emballonurid bats constitutes an important element of the bat fauna in Colombia. Herein, museum voucher specimens were used as primary source to generate a checklist of emballonurid bats from Colombia. In addition, selected museum voucher specimens were analyzed to verify their identifications. The checklist is accompanied by references as well as models of potential distribution for each Colombian emballonurid species. These distribution maps were used to investigate the affinities, in species composition, among Colombian ecoregions as outlined by Hernández-Camacho et al. (1992), and to determine emballonurid richness distribution in Colombia and the relationship between environmental variables and patterns of species richness in this group of bats in the country.

Results: We report 16 confirmed emballonurid bat species for Colombia and three species potentially present in the country, for a total of 19 species representing the eight recognized Neotropical emballonurid genera. At 16 known species, Colombia has the second greatest number of Neotropical emballonurid bats after Brazil (17 spp.).

Discussion and conclusion: The checklist presented herein is accompanied by 11 taxonomic and distributional comments explaining recent changes in taxonomy, species distribution rearrangements, as well as clarifications and a refinement of the previous records for Colombia. In addition, Geographic Information System (GIS) models of potential distribution were created for all confirmed species in Colombia, and species richness patterns were analyzed. Finally, in a Parsimony Analysis of Endemism was performed for Colombian emballonurids we found that diversity within this group of bats in geographically subdivided in Colombia into four main regions including: The Biogeographic Chocó; the Magdalena Valley; The Orinoquia; and the Guianan-Amazon region.

Key words: Chiropterans, Parsimony Analysis of Endemism, sheath-tailed bats, sac-wing bats, distribution maps.

\section{Resumen}

Se reportan 16 especies confirmadas de murciélagos embalonúridos para Colombia y tres especies potencialmente presentes en el país, que representan un total de 19

\footnotetext{
${ }^{1}$ Programa de Biología, Universidad del Quindío, Carrera 15, Calle 12 Norte Armenia, Quindío, Colombia, Sur América. E-mail: hugo.mantillameluk@gmail.com

${ }^{2}$ School of Biological Sciences, University of Queensland, Queensland, Australia. E-mail: hera.chaves@gmail.com ${ }^{3}$ Universidad Tecnológica del Chocó, Diego Luis Córdoba, Quibdó, Chocó, Colombia. E-mail: alexmauriciojimenez@ gmail.com (AMJ-O).

${ }^{4}$ Pontificia Universidad Javeriana, Bogotá D. C., Colombia. E-mail: migrodriguezp@gmail.com

*Corresponding author
} 
especies, que incluyen a los ocho géneros de embalonúridos neotropicales reconocidos. Estas 16 especies, posicionan a Colombia como el segundo país en número de especies de embalonúridos del Neotrópico después de Brasil (17 spp.). La lista está acompañada de 11 comentarios que explican cambios recientes en la taxonomía y arreglos en la distribución para el grupo; así como aclaraciones sobre los registros de embalonúridos analizados. Adicionalmente, se crearon modelos de distribución potencial de especies, basados en Sistemas de Información Geográfica (SIG), para las especies confirmadas en Colombia y se analizaron los patrones de riqueza derivados de su superposición. Finalmente, se condujo un Análisis de Parsimonia de Endemismo para los embalonúridos de Colombia, con algunos comentarios sobre la biogeografía del grupo.

Palabras clave: Análisis de Parsimonia de Endemismo, mapas de distribución, murciélagos de cola, murciélagos de alas con bolsillos, quirópteros.

The family Emballonuridae was first recognized as a distinct group by Gervais in 1855 .

Introduction

There are two supraspecific taxonomic proposals to organize the diversity contained within Neotropical sheath bats: Simmons (2005) placed Neotropical emballonurids in a single subfamily (Emballonurinae), and commented that McKenna and Bell (1997) subdivided the subfamily Emballonurinae into two tribes: Diclidurini, including all Neotropical forms; and Emballonurini containing the genera: Mosia, Emballonura, and Coleura. In contrast, Hood and Gardner (2008), assert that Neotropical emballonurids are represented by two subfamilies: Diclidurinae (Gray 1866), including the genera Diclidurus and Cyttarops; and Emballonurinae (Gervais 1856), including the genera: Balantiopteryx, Cormura, Peropteryx, and Saccopteryx. The most recent systematic assessments (Lim et al. 2004, Lim 2007, Lim et al. 2008) regard all Neotropical emballonurids as part of the tribe Diclidurini. Genetic data hypothetically place the origin of the most recent common ancestor of the subfamily Emballonurinae in Africa, suggesting a dispersal event from Africa to South America during the Oligocene (30 $\mathrm{Ma})$, and a subsequent allopatric radiation in the New World resulting in the tribe Diclidurini (Lim et al. 2004).

Diclidurinin bats have dispersed throughout the continental Neotropics, not reaching the Caribbean except for Peropteryx trinitatis, present as far north as Grenada. Emballonurid genera exist in Central America where, to date, only one event of diversification has been documented for Balantiopteryx before the completion of the Isthmus of Panama land connection in the Pliocene. This scenario was independently corroborated by a molecular analysis of the mitochondrial ND3-4 gene region (Lim et al. 2004).

Fossil records have been reported from the Miocene Colombian deposits of La Venta (12.5 - 12.3 Mya). Colombian fossil records include a small form of Diclidurus, and a specimen of an undetermined genus, which might represent a new taxon, sharing some characters of its upper canine with both Old World and New World emballonurids (Czaplewski 1997, Czaplewski et al. 2003). Although some Neotropical emballonurid species have wide distributions and are locally abundant, there are distributional gaps to examine in order to obtain a better understanding about their ecological requirements. 
Herein, museum voucher specimens were used as primary source to generate a checklist of emballonurid bats from Colombia. In addition, selected museum voucher specimens were analyzed to verify their identifications. To facilitate the comparison of our checklist to that of Alberico et al. (2000) and Solari et al. (2013; the most comprehensive checklists of Colombian mammals available to date), we follow their format. Differences between Alberico et al. (2000), Solari et al. (2013) and the current checklist are highlighted by symbols in the table containing the list, and they are explained in more detail in the text.

The checklist is accompanied by references as well as models of potential distribution for each Colombian emballonurid species. These distribution maps were used to investigate the affinities, in species composition, among Colombian ecoregions as outlined by Hernández-Camacho et al. (1992), and to determine emballonurid richness distribution in Colombia and the relationship between environmental variables and Materials patterns of species richness in this group of bats in the country.

\section{and Methods}

Museum specimens. In order to create the checklist, we reviewed Colombian emballonurid bat records in museum collections in Colombia and the United States, as well as records reported in the scientific literature (Appendix I).

Distribution models. Models of potential distribution were created for each emballonurid bat species present in Colombia using 1,165 museum georeferenced records. Records by institution are presented in Appendix II. The georeferencing process was based upon information obtained from electronic gazetteers available at www.fallingrain.com and the National Geospatial Intelligence available at: http:// geonames.nga.mil/ggmaviewer/MainFrameSet.asp. Georeferenced Colombian emballonurid sampling localities were converted into point polygon layer in ArcGIS 9.3. Each layer representing species distributional points was placed over a polygon layer of Neotropical ecoregions obtained from the website of the World Wildlife Fund (http//:www.wwf.org). Ecoregions intercepting species distributional records were selected using the Select by location option of ArcGIS 9.3 and exported as vector files. The exported files representing selected ecoregions were set as masks in the Spatial Analyst extension of ArcGIS 9.3.

Raster layers representing minimum and maximum species elevational limits were then created for each species based on elevational ranges reported in the literature (Table 1). Digital information on elevation for the Neotropics was derived from a Digital Elevation Model (DEM) available at the website WorldClim (http://www.worldclim. org/bioclim.htm; script incorporated into the Spatial Analyst extension of ArcGIS 9.3: [sp_name_altitudinal_range] $=([\mathrm{DEM}]>=$ minimum altitudinal value AND [DEM] $<=$ maximum altitudinal value). Raster files were double delimited by ecoregion and elevational ranges. Final models were classified with cell value of one (1) for species presence and zero (0) for species absence. Cell size of our raster files was adjusted to represent $1 \mathrm{~km}^{2}$. Models of potential distribution of emballonurid species present and potentially present in Colombia are presented in Appendix III. 
Table 1. List of emballonurid bats from Colombia. Symbols are as follows: additions and changes to Solari et al. (2013) $(+)$; endemic (o); taxonomic comments and consideration $(\bullet)$. Elevational range in meters. Abbreviations of Colombian departments: Amazonas (ama); Antioquia (ant) (1); Arauca (ara); Atlántico (atl); Bolivar (bl) (2); Boyacá (by); Caldas (cl); Caquetá (caq); Casanare (cas); Cauca (cau); Cesar (ce); Chocó (cho); Córdoba (co); Cundinamarca (cun); Guainía (gn); Guaviare (gv); Huila (hu); La Guajira (gua); Magdalena (ma); Meta (met); Nariño (na); Norte de Santander (nsn); Putumayo (pu); Quindío (qui); Risaralda (ri); San Andrés (sand); Santander (snt); Sucre (su); Tolima (to); Valle del Cauca (vc); Vaupés (va); Vichada (vi). Abbreviations of Colombian natural regions: Amazon (amz); Andean (and); Caribbean (car); Orinoquia (ori); and Pacific (pac). References column include previous mentions in scientific literature used as source for records included in Appendix II and III. Specimens reported by Brother Nicéforo María (1947) disappeared with the destruction of the Museo de La Salle in Bogotá.

\begin{tabular}{|c|c|c|c|c|c|}
\hline Genus & Author & Region & Department & Elevation & Reference \\
\hline Balantiopteryx $\bullet 1$ & Peters 1867 & & & & \\
\hline Balantiopteryx infusca $\bullet 2$ & Thomas 1897 & pac & ve & $400-1200$ & $\begin{array}{l}\text { Alberico et al. } \\
2000\end{array}$ \\
\hline Centronycteris + & Thomas 1912 & & & & \\
\hline Centronycteris centralis $\bullet 3,4$ & Thomas 1912 & and car & ant ? $\mathrm{cl}$ co sn vc & $50-420$ & $\begin{array}{l}\text { Lemke et al. } \\
1982\end{array}$ \\
\hline Cormura & Peters 1867 & & & & \\
\hline Cormura brevirostris $\bullet 5$ & Wagner 1843 & $\mathrm{col}$ & $\begin{array}{l}\text { ama ant bl cau } \\
\text { cl cho cq cun } \\
\text { ma met vc }\end{array}$ & $0-1400$ & Sanborn 1932 \\
\hline Cyttarops & Thomas 1913 & & & & \\
\hline Cyttarops alecto $\bullet 6$ & Thomas 1913 & $\mathrm{amz}$ & ama & $0-500$ & $\begin{array}{l}\text { Ochoa et al. } \\
1994\end{array}$ \\
\hline Diclidurus & $\begin{array}{l}\text { Wied-Neuwied } \\
1820\end{array}$ & & & & \\
\hline Diclidurus albus $\bullet 7$ & $\begin{array}{l}\text { Wied-Neuwied } \\
1820\end{array}$ & $\begin{array}{l}\text { amz and } \\
\text { car pac }\end{array}$ & cq co met ns vc & & $\begin{array}{l}\text { Goodwin and } \\
\text { Greenhall } 1961\end{array}$ \\
\hline Diclidurus ingens $\bullet 8$ & $\begin{array}{l}\text { Hernández- } \\
\text { Camacho } 1955\end{array}$ & amz pac & ama cq cho & $0-500$ & $\begin{array}{l}\text { Hernández- } \\
\text { Camacho } 1955\end{array}$ \\
\hline Diclidurus scutatus •9 & Peters 1869 & $\mathrm{amz}$ & va & 100 & $\begin{array}{l}\text { Escobedo and } \\
\text { Velazco } 2012\end{array}$ \\
\hline Peropteryx & Peters 1867 & & & & \\
\hline Peropteryx kappleri & Peters 1867 & $\begin{array}{l}\text { and car } \\
\text { pac }\end{array}$ & $\begin{array}{l}\text { ant bo ca cl cun } \\
\text { snt nsn vc }\end{array}$ & $0-1800$ & $\begin{array}{l}\text { Nicéforo María } \\
1947\end{array}$ \\
\hline Peropteryx leucoptera & Peters 1867 & ori & cas met & $0-500$ & $\begin{array}{l}\text { Lemke et al. } \\
\text { 1982; Suárez- } \\
\text { Castro et al. } \\
2012\end{array}$ \\
\hline Peropteryx macrotis & Wagner 1843 & $\begin{array}{l}\text { amz and } \\
\text { car pac } \\
\text { ori }\end{array}$ & $\begin{array}{l}\text { ant ama bl bo } \\
\text { cau cq ce gn hu } \\
\text { lg mag met nsn } \\
\text { pu snt su vc vch }\end{array}$ & $0-1800$ & Allen 1900 \\
\hline Peropteryx pallidoptera & $\begin{array}{l}\text { Lim, Engstrom, } \\
\text { Reid, Simmons, } \\
\text { Voss and Fleck } \\
2010\end{array}$ & amz ori & cq met & $0-500$ & $\begin{array}{l}\text { Suárez-Castro } \\
\text { et al. 2012; } \\
\text { Morales- } \\
\text { Martínez } 2013\end{array}$ \\
\hline Rhynchonycteris & Peters 1867 & & & & \\
\hline Rhynchonycteris naso & $\begin{array}{l}\text { Wied-Neuwied } \\
1820\end{array}$ & $\mathrm{col}$ & $\begin{array}{l}\text { ama ant bl bo cl } \\
\text { cq ce cho co gn } \\
\text { mag met put snt } \\
\text { su va vc vch }\end{array}$ & $0-500$ & Allen 1900 \\
\hline Saccopteryx & Illiger1811 & & & & \\
\hline $\begin{array}{l}\text { Saccopteryx } \\
\text { antioquensiso } \bullet 10\end{array}$ & $\begin{array}{l}\text { Muñoz and } \\
\text { Cuartas } 2001\end{array}$ & and & ant & 2171 & $\begin{array}{l}\text { Muñoz and } \\
\text { Cuartas } 2001\end{array}$ \\
\hline Saccopteryx bilineata $\bullet 11$ & Temminck 1838 & $\mathrm{col}$ & $\begin{array}{l}\text { ama ant bl ca cl } \\
\text { cq ce cho co cu } \\
\text { hu lg mag met } \\
\text { na snt su vc vch }\end{array}$ & $0-1051$ & Dobson 1878 \\
\hline
\end{tabular}




\begin{tabular}{|c|c|c|c|c|c|}
\hline Saccopteryx canescens & Thomas 1901 & $\begin{array}{l}\text { amz and } \\
\text { car ori }\end{array}$ & $\begin{array}{l}\text { ant bl cas lg } \\
\text { mag to }\end{array}$ & $0-450$ & $\begin{array}{l}\text { Nicéforo María } \\
1947\end{array}$ \\
\hline Saccopteryx leptura & Schreber 1774 & $\mathrm{col}$ & $\begin{array}{l}\text { ama ant cq cau } \\
\text { ce cho gn lg } \\
\text { mag met nsn pu } \\
\text { to va vc }\end{array}$ & $0-610$ & Bangs 1900 \\
\hline
\end{tabular}

Patterns of species richness. A model of emballonurid species richness in Colombia was produced by combining all raster files representing individual species distribution models in the Spatial Analyst extension of ArcGIS 9.3.

Correlation between richness and environmental variables. A raster layer representing the Colombian territory was created with a cell size of $0.05 \mathrm{dpi}$ and later each cell was converted into points by applying the Conversion tool in the Spatial Analyst extension of ArcGIS 9.3; as a result of this procedure we obtained a point layer of 397 points.

This point grid was used to extract values from the species richness model, using the Extract values to point tool in the Spatial Analyst extension of ArcGIS 9.3. The same procedure was applied to raster layers representing elevation, evapotranspiration, mean annual temperature, minimum temperature of the coldest month of the year, maximum temperature of the warmest month of the year, mean annual precipitation, and vegetation (climate data from www.diva-gis.org/climate.htm). Databases associated with the point layers extracted from each environmental variable, as well as the database associated with the richness point layer, were combined into a single database and exported to the statistical package PAST (version 1.90), available at folk.uio.no/ohammer/past, and a Spearman correlation was performed among richness and environmental variables.

Parsimony Analysis of Endemism (PAE) for Colombian emballonurid bats. To identify biogeographic affinities among Colombian natural regions for emballonurid bats, a Parsimony Analysis of Endemism (PAE) was performed for the 16 recognized species for the country, based upon the arbitrary subdivision of the Colombian territory into a grid of 114 quadrants. A hypothetical ancestral area, with total absence of species, was added to the data matrices in order to group by presence rather than by absence of taxa. The program Winclada (Nixon 2002) was used to build the matrix as a subsequent interface for parsimony analysis using NONA (Goloboff 1993). The PAE was performed in TNT (Goloboff et al. 2008).

\section{Results and}

\section{Discussion}

List summary. We report 16 confirmed emballonurid species for Colombia (Table 1) and three species potentially present in the country: Centronycteris maximiliani potentially present in the Amazon and Orinoquia, based upon records from Venezuela); Diclidurus isabella, potentially present in the Amazon and Orinoquia, based upon records from Brazil and Venezuela; and Peropteryx trinitatis, potentially present in the Orinoquia, based upon records from Venezuela; for a total of 19 species representing eight genera.

At 16 known species, including the endemic Saccopteryx antioquensis, Colombia has the second greatest number of Neotropical bat species of emballonurid bats, after 
Brazil (17 spp.) surpassing other countries of larger geographic area and greater overall mammalian diversity such as Mexico, Peru, and Venezuela (Table 2).

\begin{tabular}{lcl}
\hline Country & Number of species & Reference \\
\hline Brazil & 17 & *Paglia (2012) and de Castro et al. (2012) \\
Colombia & 16 & This work \\
Venezuela & 15 & Sánchez and Lew (2012) \\
Peru & 12 & Pacheco et al. (2009) \\
Ecuador & 10 & Tirira (2007) \\
Bolivia & 8 & Aguirre et al. (2010) \\
Costa Rica & 9 & LaVal and Rodríguez-H. (2002) \\
Mexico & 9 & Ceballos and Oliva (2005) \\
\hline
\end{tabular}

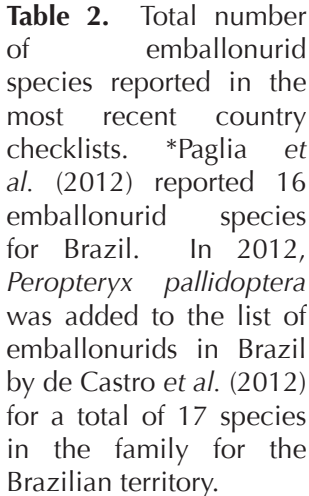

Brazilian territory.

Taxonomic and distribution comments. Eleven taxonomic and distributional comments are included, designated by $\bullet$ in Table 1 :

-1) Balantioptexyx plicata: We consider the presence of this species as dubious in Colombia, following Solari et al. (2013). Cuervo-Díaz et al. (1986) listed B. plicata as present in the Colombian Caribbean (Villanueva, department of La Guajira), based upon a specimen supposedly deposited at the collections of the Universidad Autónoma de México (UNAM), a hypothesis followed by Alberico et al. (2000), and Muñoz (2001). We found no museum records deposited in Colombian collections supporting the presence of B. plicata in the country. Balantioptexyx plicata has been reported from Mexico to Central Costa Rica (LaVal and Rodríguez-H. 2002) and it is not considered as part of the South American fauna by Jones and Hood (1993), and Hood and Gardner (2008).

-2) Balantiopteryx infusca: the species was incorrectly included as potentially present in the department of Caquetá, based on "nearby localities" by Marín-Vásquez and AguilarGonzález (2005:216). However, their conclusion was based on seven specimens deposited at the Instituto de Ciencias Naturales, Universidad Nacional de Colombia (ICN) (ICN 7737-39 and ICN 9312-15) collected in Río Engaño, and El Chanco respectively, both localities in the department of Valle del Cauca, on the western versant of the Colombian Andes. We restricted the distribution of $B$. infusca to the western versant of the Colombian Andes along the piedmonts of the Biogeographic Chocó and considered Alberico et al. (2000) inclusion of the species within the Andean region in that sense. To date, there is no indication of a trans-Andean flow for this taxon (Lim et al. 2004). McCarty et al. (2000) provides information on the ecology of collecting localities of $B$. infusca and listed the rainforest of northern Ecuador as the typical ecotype for the species.

-3) Centronycteris centralis: The presence of the species in the department of Antioquia is supported by a specimen collected at La Tirana, $25 \mathrm{~km} \mathrm{~S}$, and $22 \mathrm{~km} \mathrm{~W}$ of Zaragoza $\left(7^{\circ} 21^{\prime} \mathrm{N},-75^{\circ} 03^{\prime} \mathrm{W}\right)$ by $\mathrm{N}$. Peterson and deposited at the University of Washington 
Zoological Museum (UWZM) (o'UWZM-NEP 291170). Although Cuartas-Calle and Muñoz-Arango (2003) reported C. centralis as present in the department of Antioquia, their assumption was based on records from localities adjacent to the department. The specimen of Centronycteris centralis deposited at the Field Museum of Natural History FMNH (no catalogue number provided by authors) in Cuartas-Calle and Muñoz-Arango (2003), corresponds to specimen FMNH 98230 collected by F. Medem on February first 1963 (collectors number 125), at Alto Uré, department of Córdoba $\left(7^{\circ} 46^{\prime} \mathrm{N},-75^{\circ} 31^{\prime} \mathrm{W}\right.$, $141 \mathrm{~m})$. Alto Uré is adjacent to the northern border of the department of Antioquia. An additional female record of $C$. centralis from the Colombian Andes (Norcasia, department of Caldas, ( $\left.5^{\circ} 39^{\prime} \mathrm{N},-74^{\circ} 50^{\prime} \mathrm{W}, 420 \mathrm{~m}\right)$, deposited at the collections of the Museo de Historia Natural de la Universidad de Caldas (MHNUCa 0441), was reported by Castaño and Corrales (2007). Norcasia is adjacent to the southeastern border of the department of Antioquia. A specimen of $C$. centralis from Anchicayá $8 \mathrm{~km} \mathrm{~W}$ of Danubio $\left(03^{\circ} 37^{\prime} \mathrm{N}\right.$, $-76^{\circ} 53^{\prime} \mathrm{W}$ ), department of Valle del Cauca is deposited at the Mammal Collection of the University of Kansas ( 9 KU 135138). Centronycteris centralis was proposed as potentially present in the Colombian Amazon region by Alberico et al. (2000), and Marín-Vásquez and Aguilar-González (2005). However, we find no specimens representing this taxon from the northern portion of the Amazon Basin.

-4) Centronycteris maximiliani: Cuervo-Díaz et al. (1986) mentioned one specimen of the species from the Colombian isolated mountainous system of the Sierra de la Macarena, extending the distribution of this taxon into the Colombian Orinoquía.

However, we found no museum specimens from this or any other locality in Colombia. Centronycteris centralis was considered as a subspecies of C. maximiliani and it may be that this is the origin of some misidentifications and misinterpretations on species geographic boundaries between these two taxa. That was the case with a specimen of C. maximiliani (American Museum of Natural History, AMNH 74820) reported by Lemke et al. (1982) and included by Alberico et al. (2000) as reference material for this taxon in Colombia. Identification of specimen AMNH 74820 was corrected by Simmons and Handley (1998) as C. centralis. Solari et al. (2013) included C. maximilliani as present in the country based upon Simmons and Handley (1998). We regard C. maximiliani as probably present in the northern portion of the Colombian Amazon and the southern Orinoquia. Our assumption is based on a single record of C. maximiliani from the Venezuela department of Amazonas in the Guianan-Amazon Biogeographic province adjacent to the department of Vichada in Colombia, reported by Linares (1998) and deposited at the AMNH ( $0^{\top} \mathrm{AMNH}$ 74820). Cuervo-Díaz et al. (1986:474) reported an additional record from "Province of Nechí, department of Antioquia." However, no museum record was associated with this locality, and probably this record refers to $C$. centralis.

-5) Cormura brevirostris: In the checklist of bats from the department of Caquetá, MarínVásquez and Aguilar-González (2005: 216) referred to specimen ICN 14597 of Cormura brevirostris as "recorded based on a misidentification" . We examined specimen ICN 14597 and confirmed its identification as C. brevirostris. Specimen ICN 14597 was previously misidentified as Peropteryx macrotis. Cormura brevirostris has also been 
recorded from the southern portion of the Colombian Amazon. We included in our list a record of $C$. brevirostris from Leticia, department of Amazonas, represented by a male specimen collected by Robert J. Baker on July 11969 (Texas Tech University Museum TTU 8825). This record was not included in Alberico et al. (2000).

-6) Cyttarops alecto: Alberico et al. (2000) reported this species from the department of Vichada apparently deposited at the Instituto Alexander von Humboldt (IAvH). However, we found no records of $C$. alecto from the department of Vichada at the IAvH. Cyttarops alecto is present in the southern portion of the Colombian Amazon with a record from Leticia, department of Amazonas reported by Ochoa et al. (1994), also included in Hood and Gardner (2008), corresponding to specimen IAvH 358, collected by H. Chiriví, R. W. Cooper, A. Diaz D. on March 10, 1972.

-7) Diclidurus albus: In Alberico et al. (2000) the distribution of D. albus in the Andean (and) region and the presence of $D$. albus in the department of Valle del Cauca (vc) were accompanied by question marks (and? vc?). We confirm the presence of $D$. albus in the department of Valle del Cauca (Andean Region). The record reported by Alberico et al. (2000) and also by Cuervo-Díaz et al. (1986) corresponds to a female specimen from Cali, department of Valle del Cauca collected by M. Arango on January $1^{\text {st }} 1949$ and preserved in fluid with extracted skull (AMNH 149167); a photograph of the skull of AMNH 149167 was used by Goodwin and Greenhall (1961: plate 9) as example of the morphology of the species. To clarify the origin of Colombian D. albus records in this work, they are presented (from west to east) as follows: a specimen from Catival Upper Río San Jorge, department of Córdoba $(120 \mathrm{~m})$ at the Colombian Caribbean Region, collected by P. Hershkovitz (collector number 3585) on July 20, 1949 deposited at the FMNH (FMNH 69366). The above mentioned record was not included in Hershkovitz (1949); three specimens from the department of Norte de Santander collected by Brother Nicéforo María in Convención, and Cúcuta respectively (Nicéforo María 1955) deposited at the museum of Instituto de La Salle (ISL, in the publication); museum vouchers of these two specimens disappeared as a consequence of the fire which destroyed the collections of the Museo de La Salle in Bogotá during the rebellion of 9 of April of 1948; a third specimen of $D$. albus (virgo) from Catatumbo region, department of Santander (skull lost in the preparation) collected by Adriano Gasparoni on October $9^{\text {th }} 1954$ close to an oil drill, was also referenced in the publication of Brother Nicéforo María (1955) as deposited at the Instituto Biffi in the city of Barranquilla, Colombia; a record from the municipio of Toledo, department of Norte de Santander collected by Germán Jurado Orozco and Guillermo Cote B. in October 2004, deposited at the IAvH; a record from the Colombia Orinoquia without precise location (Los Llanos) collected by E. Guzman in1963, deposited at the Royal Ontario Museum (ROM 75741), and a record from Villavicencio, Meta deposited at the Instituto de Ciencias Naturales (ICN 6601), preserved in fluid and collected at Villavicencio "Las Mercedes" Hacienda La Reserva, 450 m.

Although not supported by voucher specimens, we include in this revision the capture of male individual of Diclidurus, reported for the department of Vichada in an anonymous note published in the Boletín Científico, Centro de Museos, Universidad de Caldas (2012). The individual, putatively assigned to $D$. albus, was captured at the 
private reserve Bojonawi, Puerto Carreño, Vichada; 54 m, in January 7, 2012 by P. Giraldo B. The record was documented by a photograph, taken by P. Giraldo B.; no measurements are included, and authors mentioned J. H. Castaño as a contact person.

Records of D. albus introduced by Muñoz (2001) in his book Murciélagos de Colombia are incorrect.

The author mistakenly cited Marinkelle and Cadena (1972) and Tamsitt and Valdivieso (1964) in reference to Colombian records from Leticia, department of Amazonas and Turbo, department of Antioquia respectively. The same error is repeated in CuartasCalle and Muñoz-Arango (2003) who incorrectly attributed a record of D. albus from the Urabá region, department of Antioquia, to Marinkelle and Cadena (1972). We reviewed Marinkelle and Cadena (1972), as well as Tamsitt and Valdivieso (1964) and found no reference on $D$. albus in these two publications. In a personal communication with Dr. Alberto Cadena, he stated that he had never added specimens of $D$. albus to any Colombian collection. We were unable to locate the $D$. albus specimens from Turbo, Antioquia supposedly deposited in the mammal collections of the Universidad de Antioquia.

-8) Diclidurus ingens: Mantilla-Meluk et al. (2009a) extended the distribution of $D$. ingens into the Biogeographic Chocó based on a record from Cértegui, department of Chocó deposited at the Colección Mastozoológica del Chocó (CMCH 001649). This record constituted the only record from this taxon from the western versant of the Andes.

Although the morphology observed in specimen $\mathrm{CMCH} 001649$ was closer to $D$. ingens, Mantilla-Meluk et al. (2009a) highlighted some morphological differences present in their $D$. ingens Chocoan specimens with respect to Colombian known specimens from the eastern versant of the Andes, raising the possibility of cryptic diversity within this taxon.

-9) Diclidurus scutatus: This species was considered potentially present in Colombia based on Venzuelan records reported by Linares (1998) from localities adjacent to the Colombo-Venezuelan border. Marinkelle and Cadena (1972) followed Cuervo-Díaz et al. (1986) and listed D. scutatus as potentially present in Colombia. Escobedo and Velazco (2012), confirmed the presence of D. scutatus in the country based upon two specimens from the Lower Rio Apaporis, Yai-Gojes, deposited at the FMNH (FMNH 88234-88235).

-10) Saccopteryx antioquensis. Saccopteryx antioquensis Muñoz and Cuartas 2001, was described based on material collected at La Soledad, Municipio de Sonsón, department of Antioquia ( $5^{\circ} 36^{\prime} \mathrm{N},-75^{\circ} 56^{\prime} \mathrm{W} 2,171 \mathrm{~m}$ ). Saccopteryx antioquensis can be distinguished from other species of the genus in Colombia (S. bilineata, S. canescens, and $S$. leptura) by the absence of dorsal stripes, as well as the connection of the wing to the metatarsal and not to the ankle. Allen (1900) made reference to coat color variation among S. bilineata including differences in the distinctiveness of the dorsal stripes. The author refers to this variation as follows: "The white markings on the back (of $S$. bilineata) vary much in distinctness in different specimens, being sometimes almost clear white and strongly defined, in other specimens brownish white, and sometimes 
obsolete". Allen also mentioned that an almost uniform color is common among juvenile $S$. bilineata.

Muñoz and Cuartas (2001) considered S. antioquensis closely related in morphology to the alloptaric S. gymnura. Saccopteryx antioquensis can be differentiated from $S$. gymnura by its larger size (forearm 36.2-38.0) (Muñoz and Cuartas 2001). Although Lim et al. (2007) were unable to include $S$. antioquensis in their phylogenetic analyses, due to the unavailability of tissues of the only two known specimens representing this taxon they proposed a split of the common ancestor of $S$. gymnura from $S$. canescens around 6 Mya. This evidence, in conjunction with differences in ecological requirements of $S$. antioquensis with respect to other species in the genus leads us to hypothesize an evolutionary scenario for the divergence of $S$. antioquesis associated with the Andean uplifting. Saccopteryx gymnura with type locality in Santarem, Pará, Brazil, is known only from the northeastern Guiana and is not present in Colombia.

-11) Saccopteryx bilineata: This species is widespread, and is distributed in Neotropical lowlands from Mexico (Ceballos and Oliva 2005) to southeastern Brazil (Simmons 2005). Elevational ranges proposed for $S$. bilineata across its distribution are all below $800 \mathrm{~m}$, including 98 S. bilineata localities in Venezuela which are within a $0-630$ $\mathrm{m}$ elevational range reported by Linares (1998). Among Colombian records recovered from the literature, there is a specimen of $S$. bilineata from Bogotá, Colombia $(2,600 \mathrm{~m})$, reported by Dobson (1878) in his revision of material deposited at the British Museum. It is likely that the Colombian S. bilineata reported by Dobson (1878) are from an unknown locality in the lowlands surrounding Bogotá in the department of Cundinamarca. Known records of $S$. bilineata from de department of Cundinamarca include a female specimen reported by Tamsitt and Valdivieso (1963) collected at Girardot (4 $4^{\circ} 18^{\prime} 11 \mathrm{~N},-74^{\circ} 48^{\prime}$ 3W, $223 \mathrm{~m}$ ) (not included in Alberico et al. 2000), on October 281961 by James R. Tamsitt (JRT-1418), preserved in alcohol and deposited at the American Museum of Natural History (AMNH 207767). There is a second specimen (AMNH 207928) from the same locality collected by James R. Tamsitt on October 15 1961, without collector' s number. Allen (1900) mentioned two well-marked color phases black and brown among S. bilineata from the Colombia Caribbean, with a few intermediate specimens between the two phases.

General emballonurid distributional patterns. The Colombian territory is ecosystemically diverse due to a combination of complex geologic, ecological, and biogeographic processes that result in a variety of niche opportunities for bats (Mantilla-Meluk et al. 2009b). The geographic diversity of the Colombian territory can be divided into five natural regions: Amazon, Andean, Caribbean, Orinoquia, and Pacific (Chocó), each one characterized by unique arrangements of ecological variables (Hernández-Camacho et al. 1992). Our analysis revealed that richness distribution among emballonurids decreased with elevation, with the Andes as a major barrier separating allopatric emballonurid populations from the eastern and western versants of the system (Fig. 1). The greatest number of emballonurid species is associated with the lowlands of the upper Amazon (10 spp.), followed by the eastern piedmonts of the Eastern Cordillera; the northern portion of the Colombian Orinoquia; and the Biogeographic Chocó (each with more 
than seven species; Fig. 1). A large number of species were shared among regions (Table 3, Appendix II, IV) with only five species documented from only one region: C. alecto (Amazon), D. scutatus (Amazon), S. antioquensis (Andean), P. leucoptera (Orinoquia), and $B$. infusca (Pacific). The Amazon and the Orinoquia are more similar and shared the largest number of species (8 spp.); while the Biogeographic Chocó and the Orinoquia are the most dissimilar regions sharing only five species.

Figure 1. Emballonurid richness distribution in Colombia. Warm colors represent areas with a higher number of sympatric emballonurid species and cold colors represent areas with a lower number of emballonurids.

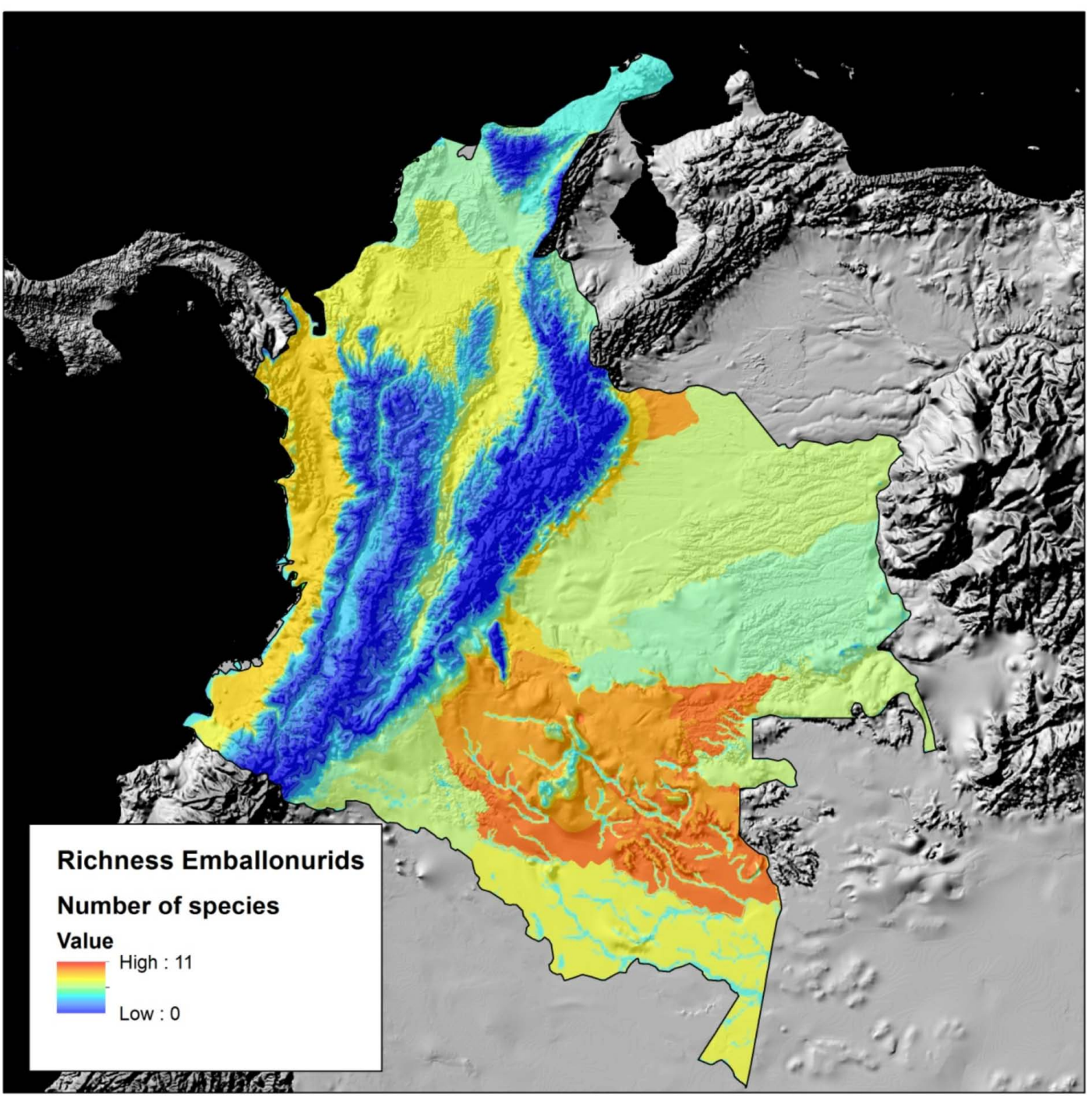

Table 3. Number of emballonurid species shared among Colombian natural regions, based on voucher specimens.

\begin{tabular}{lcccc}
\hline & Amazon & Andean & Caribbean & Orinoquia \\
\hline Amazon & - & & & \\
Andean & 7 & - & & \\
Caribbean & 7 & 8 & - & \\
Orinoquia & 8 & 5 & 6 & - \\
Pacific & 7 & 7 & 5 & 5 \\
\hline
\end{tabular}

Our multiple correlations between emballonurid richness and environmental variables showed that emballonurid richness in Colombia had a significant, positive correlation with evapotranspiration, and a significant, negative correlation with elevation (Table 4). 
Higher numbers of species were found in areas with average precipitation greater than 2,000 $\mathrm{mm}$, average temperature greater than $25^{\circ} \mathrm{C}$, and elevations lower than $500 \mathrm{~m}$. These conditions are widely distributed across the Colombian geography, in all natural regions of the country.

In our species richness model, the largest number of species was associated with the Guianan-Amazon corridor (Fig. 1), characterized by terraces (200 to 500 m) of Cambric origin associated with the Guiana Shield. These terraces constitute emergent land masses that potentially recruited terrestrial flora and fauna during the repeated invasions of water masses on the lowlands of northwestern South America during the Miocene. For a significant part of the Early to Mid-Miocene (23-17 Mya), the Colombian Amazon was under the influence of the lake formation of Pebas (Wesselingh and Salo 2006). Subsequent inundations were apparently frequent during the mid and late Miocene (Hovikoski et al. 2007, and references therein) and elevations greater than $200 \mathrm{~m}$ could play an important role in the establishment of emballonurid populations.

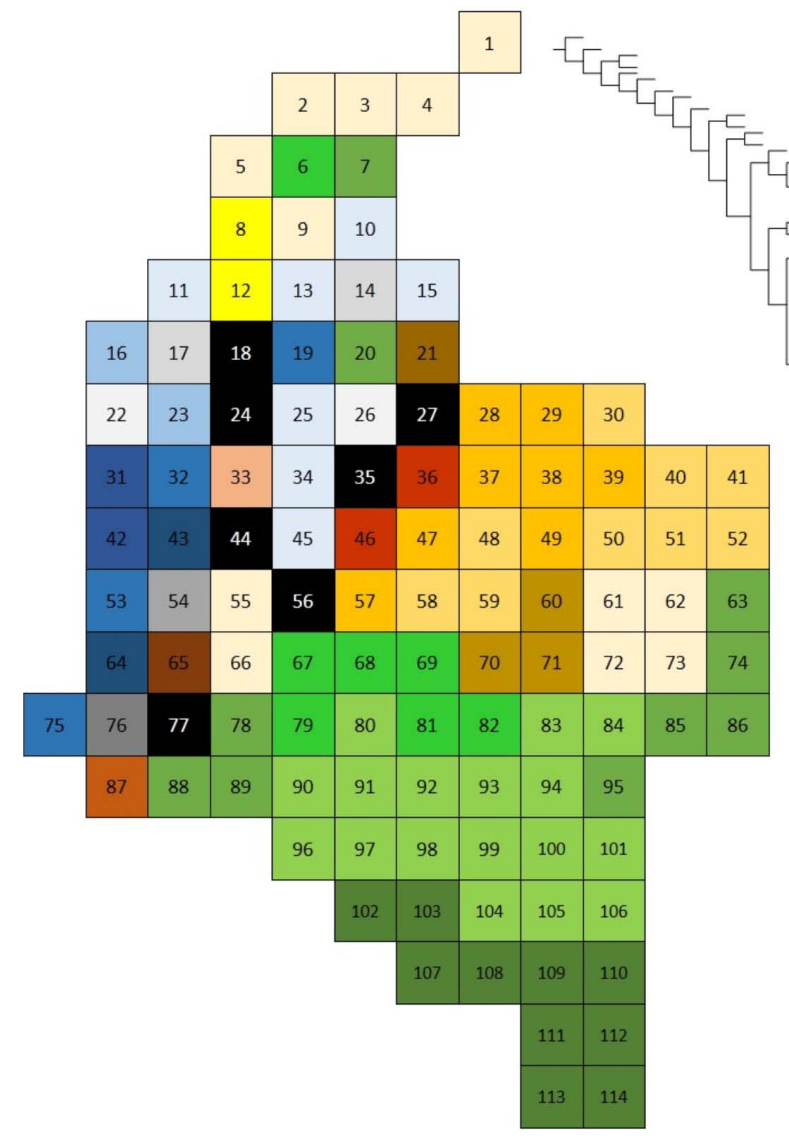

\section{Biogeográphic Choco}

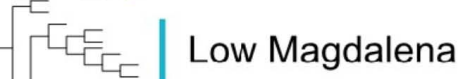

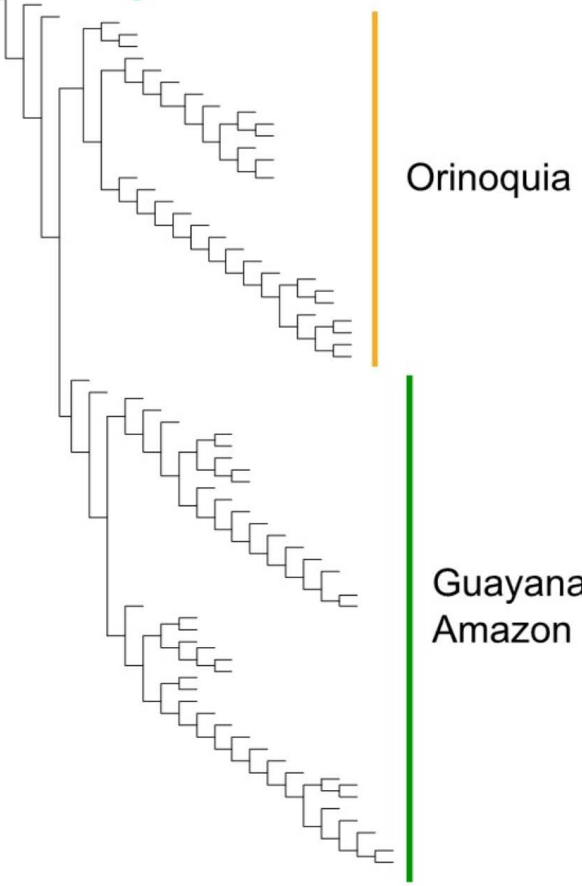

Figure 2. Parsimony Analysis of Endemism of Colombian emballonurid bats. Emballonurid diversity was geographically subdivided into four major clades representing the Amazon Guianan region (green quadrants); the Colombian Orinoquia (yellow quadrants); the Biogeographic Chocó (dark blue quadrants); and the low Magdalena Valley (light blue quadrants).

Parsimony analysis of endemism. The PAE showed three subunits of higher biogeographic affinity for Colombian emballonurids: 1) Guianan Amazon region (green quadrants, Fig. 2); the Orinoquia (yellow quadrants); and 3) Biogeographic Chocó (dark blue quadrants). The Andean, as well as the Caribbean region, encloses a more variable composition of emballonurid species. Although most of the quadrants representing the Inter-Andean 
Valley of the Magdalena River in its lower portion (northern part of the country) appear in the PAE output as an independent clade, quadrant 19 was associated in composition with the Biogeographic Chocó. A biogeographic affinity between the Magdalena Valley, the western Caribbean and the Biogeographic Chocó was proposed by HernándezCamacho et al. (1992).

Globally, these results are in accordance with a vicariant pattern associated with the uplifting of the Andean System, separating Colombian Cis-Andean emballonurid fauna (Amazon and Orinoquia) from its counterpart at the western portion of the country (Biogeographic Chocó). This pattern has been documented for different groups of fauna including bats (Mantilla-Meluk et al. 2009b). In the eastern portion of the country, the piedmonts of the Andes and Altillanura of the Colombian Orinoquia enclose a large number of emballonurid species, decreasing through the southern Orinoquia. In contrast to the more constant conditions of the eastern Andean piedmonts, the southern Orinoquia is characterized by dramatic fluctuations of ecological variables (Marchant et al. 2006) potentially affecting emballonurid diversity. However, it is important to consider, that the Orinoquia is one of the less understood regions of the country and the observed pattern potentially is an artifact of low sampling efforts in this portion of the country.

\begin{tabular}{|c|c|c|c|c|c|c|c|c|c|}
\hline \multirow{8}{*}{ 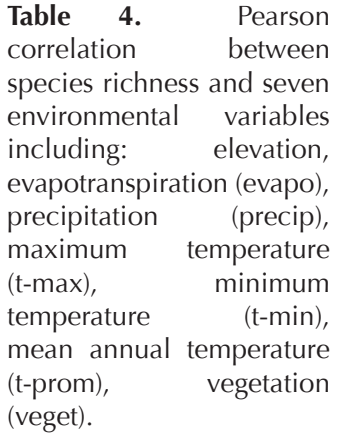 } & Correlations & Richness & elevation & evapo. & precip. & $t-\max$ & $t-\min$ & t-prom & veget. \\
\hline & Richness & 1 & & & & & & & \\
\hline & elevation & $-076 * *$ & 1 & & & & & & \\
\hline & & 1.81E-21 & . & & & & & & \\
\hline & evapo. & $0.75^{* *}$ & $-0.89 * *$ & 1 & & & & & \\
\hline & & $1.81 \mathrm{E}-21$ & $1.81 \mathrm{E}-21$ & . & & & & & \\
\hline & precip. & $0.43^{* *}$ & $-0.36^{* *}$ & $0.42 * *$ & 1 & & & & \\
\hline & & 6.7E-19 & 7.21E-13 & $7.4 \mathrm{E}-18$ & . & & & & \\
\hline & t-max & $0.68^{* *}$ & $-0.89 * *$ & $0.93 * *$ & $0.24^{* *}$ & 1 & & & \\
\hline & & $1.81 \mathrm{E}-21$ & $1.81 \mathrm{E}-21$ & $1.81 \mathrm{E}-21$ & $1.03 \mathrm{E}-06$ & . & & & \\
\hline & $t-\min$ & $0.72^{* *}$ & $-0.90^{* *}$ & $0.97^{* *}$ & $0.38^{* *}$ & $0.96^{* *}$ & 1 & & \\
\hline & & $1.81 \mathrm{E}-21$ & $1.81 \mathrm{E}-21$ & $1.81 \mathrm{E}-21$ & 8.35E-15 & $1.81 \mathrm{E}-21$ & . & & \\
\hline & t-prom & $0.73^{* *}$ & $-0.91^{* *}$ & $0.97 * *$ & $0.32 * *$ & $0.98^{* *}$ & $0.99^{* *}$ & 1 & \\
\hline & & $1.81 \mathrm{E}-21$ & $1.81 \mathrm{E}-21$ & $1.81 \mathrm{E}-21$ & $6.08 \mathrm{E}-11$ & $1.81 \mathrm{E}-21$ & $1.81 \mathrm{E}-21$ & . & \\
\hline Correlation significant at & veget. & $-0.55^{* *}$ & $0.51^{* *}$ & $-0.53^{* *}$ & $-0.36 * *$ & $-0.43^{* *}$ & $-0.48^{* *}$ & $-0.46^{* *}$ & 1 \\
\hline$(* *)$. & & $1.81 \mathrm{E}-21$ & $1.81 \mathrm{E}-21$ & $1.81 \mathrm{E}-21$ & $1.76 \mathrm{E}-13$ & 2.69E-18 & $1.81 \mathrm{E}-21$ & $1.81 \mathrm{E}-21$ & . \\
\hline
\end{tabular}

Final biogeographic considerations. The Guianan region, which includes the highest diversity of emballonurids, has been proposed as the center of radiation of diclidurine bats in the Neotropics (Lim et al. 2007). Two aspects are mentioned by Lim et al. (2007) as important for this radiation: 1) the uplifting of the Andes, and 2) climatic changes in the Early Miocene between 19.4 and 18.0 mya. Geologic reconstructions of ecogeographic conditions around Early Miocene suggest a different landscape in northern South America than that prevailing today. During the Miocene the presence of extensive savannas was more common and forested areas in the Amazon region were more reduced than 
today. During the Early Miocene the Andean system was not completely raised and an interconnection between the eastern and western versants of the proto Andes was possible along extensive areas. The Cuenca basin in Ecuador (Wesseling and Salo 2006) represents the lowest point of the Andean continental divide, and could act as a potential bridge between the two versants of the system (Fig. 3). The Trans-Andean communication between lowlands across the Cuenca Bridge was terminated around 3 Mya with the last uplifting of the Andes. On the eastern side of northern South America there was the internal lake of the Pebas system that prevailed between 23 to 8 Mya. It is likely that the Pebas formation worked as a weak barrier for lowland species between the Guianan shield and the western portion of South America. The inundated lowlands of the system may have limited the east-west communication in northern South America to the Guianan-Macarenan Bridge along the projections of the Guianan Shield into the eastern portion of the Colombian region.

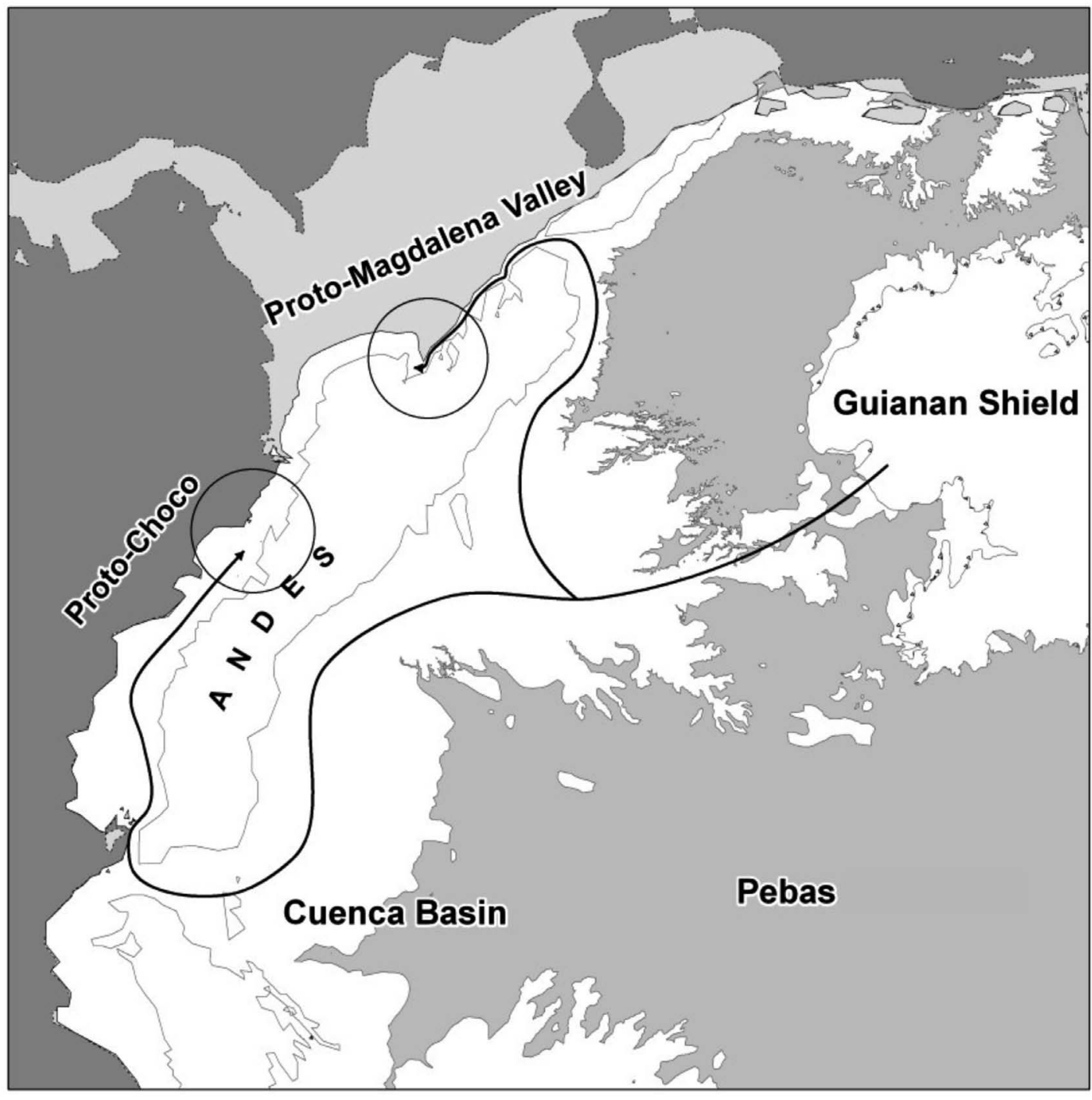

Figure 3. Reconstruction of South America landscape 18 mya, Early Miocene, and potential route of colonization of emballonurids into Central America via the Cuenca Basin (solid line). Circles represent the Proto-Chocó and Proto-Magdalena Valley respectively.

This work would not be possible without the generous help of curators and personnel in charge of the scientific collections visited. We specially thank: D. Wilson, K. Helgen, 
A. Gardner, and L. Gordon for their assistance at the mammal collections of the USNM of the Smithsonian Institution; B. D. Patterson, L. Heaney, W. Stanley, P. Velazco, and R. Baniasek for their help at the mammal collections of the FMNH; Y. Muñoz-Saba, H. López, and C. Cárdenas for their assistance at the ICN; P. Rivas at the MHNUC, Oscar Murillo at the UV; D. Perico for his collaboration at the collections of the IAvH; A. Asprilla, L. Palacios, and O. Rios for their support at the $\mathrm{CMCH}$ of the $\mathrm{UTCH}$.

\section{References}

Aguirre, L. F., C. J. Mamani, K. Barbosa-Marquez, and H. Mantilla-Meluk. 2010. Lista actualizada de los murciélagos de Bolivia. Revista Boliviana de Ecología y Conservación Ambiental 27:1-7.

Alberico, m, A. Cadena, J. Hernández-Camacho, and Y. Muñoz-Saba. 2000. Mamíferos (Synapsida: Theria) de Colombia. Biota Colombiana 1:43-75.

Alten, J. A. 1900. List of bats collected by Mr. H. H. Smith in the Santa Marta region of Colombia, with descriptions of new species. Bulletin of the American Museum of Natural History 13:89-94.

Bangs, O. 1900. List of the mammals collected in the Santa Marta region of Colombia by W.W. Brown, Jr. Proceedings of the New England Zoological Club 1:87-102

Castaño, J. H., and J. D. Corrales. 2007. Primer registro de Centronycteris centralis (Chiroptera: Emballonuridae) en los Andes colombianos. Mastozoología Neotropical 14:69-72.

Ceballos, G., and G. Oliva. 2007. Los mamíferos silvestres de México. Sociedad para el conocimiento y uso de la diversidad. Fondo de Cultura Económica. Ciudad de México, México.

Cuervo-Diaz, A., J. Hernández-Camacho, and A. Cadena G. 1986. Lista actualizada de los mamíferos de Colombia. Anotaciones sobre su distribución. Caldasia 15:471501.

Cuartas-Calle, C. A., and J. Muñoz-Arango. 2003. Lista de los mamíferos (Mammalia: Theria) del departamento de Antioquia, Colombia. Biota Colombiana 4:65-78.

Czaplewskı, N. J. 1997. Chiroptera. Pp. 410-431 en Vertebrate Paleontology in the Neotropics. The Miocene fauna of La Venta, Colombia (R. F. Kay, R. H. Madden, J. J., and Flynn eds.). Smithsonian Institute Press. Washington, EE.UU.

Czaplewski, N. J., M. Takal, T. M. Naeher, N. Shigehara, and T. Setoguchi. 2003. Additional bats from the middle Miocene La Venta fauna of Colombia. Revista de la Academia Colombiana de Ciencias Exactas, Físicas y Naturales 27:263-282.

de Castro, I. J., E. Reis dos Santos, A. C. Moreira Martins, D. Dias, and A. L. Peracchi. 2012. First record of the dog-like bat Peropteryx pallidoptera (Chiroptera: Emballonuridae) from Brazil. Mammalia 76:471-476.

Dobson, G. E. 1878. Catalogue of the Chiroptera in the collection of the British Museum. British Museum of Natural History. London, United Kindom.

Escobedo, M, and P. M. Velazco. 2012. First confirmed record for Peru of Diclidurus scutatus Peters, 1869 (Chiroptera: Emballonuridae). Check List 8:554-556.

Gervals, H. 1855. Histoire naturelle de mammiféres, avec l'indication de leurs moers, et leur rapports avec les arts, le commerce et agriculture. Paris: L. Curmer, 2:1-3 (unnumbered), 1-344. 
Goloboff, P. A. 1993. NONA, version 2.0. Program and documentation distributed by the author.

Goloboff, P. A., J. S. Faris, and K. C. Nixon. 2008. TNT a free program for phylogenetic analysis. Cladistics 24:774-786.

Goodwin, G. G., and A. M. Greenhall. 1961. A review of the bats from Trinidad and Tobago. Bulletin of the American Museum of Natural History 122:187-301.

Hernández-Camacho J. 1955. Una nueva especie colombiana para el género Diclidurus (Mammalia: Chiroptera): Diclidurus ingens. Caldasia 7:87-98.

Hernández-Camacho, J., A. Hurtado, R. Ortiz, and T. Walschburger. 1992. Unidades biogeográficas de Colombia. Pp. 105-151 en La Diversidad Biológica de Iberoamérica (I. Halffter G., ed.). Acta Zoológica Mexicana, Instituto de Ecología, A. C. Ciudad de México, México.

Hershrovitz, P. 1949. Mammals of northern Colombia: preliminary report no. 5: bats (Chiroptera). Proceedings of the United States National Museum 99:429-454.

Hood, C., AND A. L. Gardner. 2008. Family Emballonuridae. Pp. 188-207 en Mammals of South America, Volume 1 Marsupials, Xenarthrans, Shrews, and Bats (Gardner, A. L., ed.). The University of Chicago Press. Chicago, EE.UU.

Hovikoskı, J., M. Gringas, M. Räsänen, L. A. Rebata, J. Guerrero, A. Ranzı, J. Melo, L. Romero, F. JAIMES, AND S. López. 2007. The nature of Miocene Amazonian epicontinental embayment: High frequency shifts of low gradient coastline. Geological Society of America Bulletin 119:1506-1520.

Jones, J. K. JR., AND C. Hood. 1993. A synopsis of South American bats of the family Emballonuridae. Occasional Papers, The Museum Texas Tech University 155:1-30.

LaVAL, R. K., and B. Rodríguez-H. 2002. Los murciélagos de Costa Rica. Instituto Nacional de Biodiversidad, INBio, Santo Domingo, Heredia.

Lemke, T. O., A. Cadena, R. H. Pine, and J. Hernández-Camacho. 1982. Notes on opossums, bats and rodents new to the fauna of Colombia. Mammalia 46:225-234.

Lıм, B. K. 2007. Divergence times and origin of Neotropical sheath-tailed bats (tribe Diclidurini) in South América. Molecular Phylogenetics and Evolution 45:777-791.

Lim, B. K., M. D. Engstrom, N. B. Simmons, J. M. Dunlop. 2004. Phylogenetics and biogeography of least sac-winged bats (Balantiopteryx) based on morphological and molecular data. Mammalian Biology 69:225-237.

Lim, B. K., M. D. Engstron, J. W. Bickham, and J. C. Patton. 2008. Molecular phylogeny of sheath tailed bats (Dicliduruni: Emballonuridae), based on loci from the four transmission systems in mammals. Biological Journal of the Linnean Society 93:189-209.

Linares, O. J. 1998. Los mamíferos de Venezuela. Sociedad de Conservación Audubon de Venezuela. Caracas, Venezuela.

McCarty, T. J., L. Albuja, and I. Manzano. 2000. Rediscovery of the brown sac-wing bat, Balantioteryx infusca (Thomas, 1897), in Ecuador. Journal of Mammalogy 81:958961.

McKenna, M. C., and S. K. Bell. 1997. Classification of mammals above the species level. Columbia University Press. New York, EE.UU. 
Mantilla-Meluk, H., A. M. Jimenez-Ortega, L. Palacios, and R. J. Baker. 2009 a. Unexpected finding of Diclidurus ingens, Hernández-Camacho 1955 (Chiroptera: Emabllonuridae) in the Biogeographic Chocó. Mastozoología Neotropical 16:229232.

Mantilla-Meluk, H., A. M. Jimenez-Ortega, and R. J. Baker. 2009b. Phyllostomid bats from Colombia: annotated checklist, distribution, and biogeography. Special Publications Occasional Papers Museum of Texas Tech University 56:1-37.

Marchant, R., J. C. Berrío, H. Behling, A. Boom, and H. Hooghiemstra. 2006. Colombian dry moist forest transitions in the Llanos Orientales, a comparison of model and pollen-based biome reconstructions. Palaeogeography, Palaeoclimatology, Palaeoecology 234:28-44.

Marín-Vasquez, A., and A. V. Aguilar-González. 2005. Murciélagos (Chiroptera) del departamento de Caquetá-Colombia. Biota Colombiana 6:211-218.

Marinkelle, C. J., and A. Cadena. 1972. Notes on bats new to the fauna of Colombia. Mammalia 36:49-58.

Morales-Martínez, D. M. 2013. Primer registro de Peropteryx pallidoptera en ecosistemas de sabana. Therya 4:401-407.

Muñoz, J. 2001. Los murciélagos de Colombia: Sistemática, distribución, descripción, historia natural y ecología. Universidad de Antioquia. Medellín, Colombia.

Muñoz, J., and C. A. Cuartas. 2001. Saccopteryx antioquensis n. sp. (Chiroptera: Emballonuridae) del noreste de Colombia. Actualidades Biológicas 23:53-61.

Nić́foro María, H. 1947. Quirópteros de Colombia. Boletín Instituto La Salle, Bogotá 34:34-47.

Nić́foro María, H. 1955. Hallazgo de Diclidurus virgo Thomas en Colombia. Boletín Instituto La Salle 42:72-75.

Nixon, K.C. 2002. WINCLADA. Program and documentation distributed by the author.

Ochoa G., P. J. Soriano, and J. I. Hernández-Camacho. 1994. Sobre la presencia de Cyttarops alecto (Chiroptera:Emballonuridae) en Colombia. Trianae 5:411-414.

Pacheco, V., R. Cadenillas, E. Salas, C. Tello and H. Zeballos. 2009. Diversidad y endemismo de los mamíferos del Perú. Revista Peruana de Biología. 16:5-32.

Pérez-Torres, J., J. Palacio-Guerrero, C. Sánchez-Lalinde, D. Pardo-Afanador, and N. Cortés-Delgado. 2007. Catálogo de los mamíferos del Museo Javeriano de Historia Natural Lorenzo Uribe Uribe, S. J. (Pontificia Universidad Javeriana). Universitas Scientiarium edición especial 1:131-142.

Sánchez H., J. AND D. Lew. 2012 (" 2010" ). Lista actualizada y comentada de los mamíferos de Venezuela. Memoria de la Fundación La Salle de Ciencias Naturales 173/174:173-238.

Simmons, N. B. 2005. Order Chiroptera. Pp. 313-529 en Mammals Species of the World, A Taxonomic and Geographic Reference, first volume. Third Edition (Wilson D. E., and Reeder m, eds.). The John Hopkins University Press. Baltimore, EE.UU.

Simmons, N. B., AND C. O. Handley, JR. 1998. A revision of Centronycteris Gray (Chiroptera: Emballonuridae) with notes on natural history. American Museum Novitates 3239:1-28. 
Soları, S. S., Y. Muñoz-Saba, J. V. Rodríguez-Mahecha, T. R. Defler, H, E. Ramírez-Chaves, and F. Trujillo. 2013. Riqueza, endemismo y conservación de los mamíferos de Colombia. Mastozoología Neotropical 20:301-365.

Suárez-Castro, A. F., H. Ramírez-Chaves, M. E. Rodríguez-Posada, and J. García. 2012. New records of Peropteryx leucoptera and first record of Peropteryx pallidoptera (Chiroptera-Emballonuridae) from Colombia. Mastozoología Neotropical 19:165171.

Tamsitt, J. R., And D. Valdivieso. 1963. Records and observations on Colombian bats. Journal of Mammalogy 44:168-180.

TAmsitt, R. J., AND D. Valdivieso. 1964. Information sur la reproduction des cheiropteres phyllostomids de Colombie. Mammalia 28:397-402.

TiriRA, D. 2007. Guía de campo de los mamíferos del Ecuador. Ediciones Murciélago Blanco. Publicación especial sobre los mamíferos del Ecuador. Quito.

Wesselingh, F. P., and J. A. Salo. 2006. A Miocene perspective on the evolution of the Amazonian biota. Scripta Geologica 133:439-457.

Wied-Neuwied, M. Z. 1820. Diclidurus. Klappenschwanz. Ein neues genus der Chiroptera aus Brasiliaen. ISIS Oder Encyclopadische Zeitung Von Oken 4-5:1620-1630.

Sometido: 20 de enero de 2014

Revisado: 21 de marzo de 2014

Aceptado: 20 de abril de 2014

Editor asociado: Robert Owen

Diseño gráfico editorial: Gerardo Hernández

Specimens examined

Colección Mastozoológica del Chocó (CMCH); Instituto Alexander von Humboldt (IAvH); Instituto de Ciencias Naturales (ICN); Field Museum of Natural History (FMNH); Museo de Historia Natural Universidad del Cauca (MHNUC); Muséum d' Histoire Naturelle de Genève (MHNG); Natural History Museum, University of Kansas (KU); Texas Tech University (TTU); United State National Museum, Smithsonian Institution (USNM); Universidad del Valle (UV).

Balantiopteryx infusca. Valle del Cauca: Calima (Darién), Río El Chanco, 400m, ICN 9309-16. Río Engaño, carretera vieja de Cali a Bucaramanga. Pared rocosa 200 m desde el puente (rio arriba), ICN 7737-39 $(n=8)$. 
Centronycteris centarlis. Caqueta: Colombia: Depto. Caquetá. PNN. Chiribiquete. Sector Suroriental. Rio Mesay. Puerto Abeja. $0^{\circ} 04^{\prime} 27^{\prime \prime} \mathrm{N} ;-2^{\circ} 27^{\prime}$ 05" W, 250 m. Cundinamarca: Nocaima, Vereda La Forida. En cueva pequeña, ICN 1671. Monteria: Corregimiento Tres Piedras, Caserío Maracayo, sitio El Lúcido, ICN 1720. Valle del cauca: Anchicayá 8 km W of Danubio, 03³7' N, - 76²53’ W, KU 135138.

Cormura brevirostris. CAQUETA, P. N. N. Chiribiquete, sector suroriental, Rio Mesay. Puerto Abeja $0^{\circ} 04^{\prime} 27^{\prime \prime} \mathrm{N}$; - 72 ${ }^{\circ} 27^{\prime}$ 05" W, 250 m, IAvH 7139. Chocó: Granja UTCH CMCH 00258. Meta: Cueva en la escarpa sobre el campamento No 1, extremo meridional de la Sierra de La Macarena, ICN 665. Municipio San Juan de Arama, parte norte Serranía La Macarena, Caño La Curia, \pm 500 m ICN 10220. Córdoba: Catival, Río San Jorge, FMNH 69344; FMNH 69346-47.

Cyttarops alecto. Amazonas, Leticia; Trocha a Calderón aproximadamente 35-40 km de Leticia, IAvH 358,

Diclidurus albus. Córdoba: Catival Upper Río San Jorge, FMNH 69366. Meta: Villavicencio "Las Mercedes" Hda La Reserva, 450 m, ICN 6601. Norte De Santander, Toledo 1a Curva, salida Toledo-Chinacota 1,642 m. Vaupes [Guaviare], Río Guaviare frente a las bocas del rio Ariari, $350 \mathrm{~m} \mathrm{IAvH} \mathrm{3520;} \mathrm{IAvH} 3542$

Diclidurus ingens. Caqueta: Puerto Leguízamo, ICN 546. Chocó: Cértegui CMCH 001649.

Diclidurus scutatus. Vaupes: Lower Río Apaporis, Yay Gojes, FMNH 88234-35.

Peropteryx kappleri. Antioquia: Municipio Puerto Nare, Vereda Chorro de Oro, Finca Buena Vista, caverna Ilusiones 1,580 m, ICN 13295. Municipio San Luis, Montes de La Mulata, cueva "Mauro 2", 630 m, ICN 13296. Boyaca: Santa Ana, cueva orilla carretera, 1750 m ICN 9106. Caldas: Municipio Samaná, Corregimiento Norcasia, alrededores campamento CHEC, 650 m ICN 10779; ICN 15952. Cundinamarca: Utica, Granja Agropecuaria de la Universidad Nacional, ICN 483-86. La Mesa, 1,300 m, ICN 516; ICN 537; ICN 862; ICN 917. Santander: Barrancabermeja, Caño de Peroles, ICN 859; ICN 4701. Valle Del Cauca: Cali, aproximadamente 2 km S, USNM 483280-89. Jamundí, en mina de carbón aproximadamente a $10 \mathrm{~km}$ al Sureste, ca. 1,200 m, ICN 4977-79. Yumbo, Mulalo mina de calcita (aproximadamente $10 \mathrm{~km} \mathrm{~N}$ Yumbo), ca. 1,200 m, ICN 4980-84. Cali, 2 km S, ICN 5825. Cali, mina de carbón cerca plaza de toros, ICN 5826; ICN 5827. Cali, minas de carbón en Siloé, ICN 582830. Cali, Barrio Caldas en mina de carbón, ICN 5831. Cali, Barrio Caldas, mina de carbón cerca hospital Los Chorros, 1000 m, ICN 5832-35. Yumbo, \pm 10 km N en mina de calcita en Mulalo, ICN 5836-39. Jamundí, mina de carbón en carretera a San Antonio, ICN 5840-43; Jamundí, en mina de carbón \pm 10 km SO, ICN 5844-68; Jamundí, en mina de carbón. Las Brujas, ICN 5869. Calima (Darién), Río Calima, camino El Chanco a Río Azul, ICN 9317-25. Potrerito SW Jamundí USNM 461843-46. Peropteryx leucoptera. Casanare: San Luis de Palenque, Vereda La Venturosa, Finca El

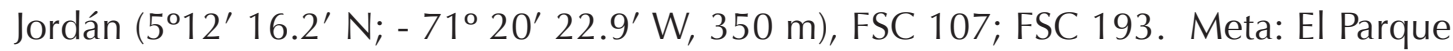
la Macarena, 30 m NW Camp. Izawa, Río Duda, Campamento Chamusa, 2 ${ }^{\circ} 42^{\prime} \mathrm{N}$, 74¹0' W, 250 m IAvH 2241. Puerto Gaitán, Campo Rubiales, bloque Kifa Este, 0350` N; 71057` W, 350 m, Número de colector HERC 768-69.

Peropteryx macrotis. COLOMBIA: MHNG 1906.031. Amazonas: Caserío de Araracuara, ICN 8501. Antioquia: Puerto Triunfo, Hacienda El Refugio, Rioclaro, 280 
m, ICN 9760-61. Municipio Pto. Nare, Vereda Chorro de Oro, Finca Buena Vista, 580 m, ICN 13297-13300. Bolivar: Bahía de Cartagena, Isla de Tierrabomba, poblado de Bocachica, ICN 3903-07. Isla de Tierra Bomba, Fort de Boca Chica (dans une galerie), MHNG 1926.023-26; MHNG 1924.055; MHNG 1923.062. Isla de Tierra Bomba, En Cisterna (planta) arriba de Caño de Loro, MHNG 1923.003, MHNG 1923.002, MHNG 1923.001, MHNG 1922.100. Isla de Tierra Bomba (Cartagena), Fort de Boca Chica, direction Ponton, MHNG 1915.032; MHNG 1915.031; MHNG 1915.030; MHNG 1915.029; MHNG 1915.028; MHNG 1915.027; MHNG 1915.026; MHNG 1915.025; MHNG 1915.024; MHNG 1915.023; MHNG 1915.022; MHNG 1915.021; MHNG 1915.020; MHNG 1915.019; MHNG 1915.018; MHNG 1915.017; MHNG 1915.016; MHNG 1915.015; MHNG 1915.014; MHNG 1915.013; MHNG 1915.012; MHNG 1915.011; MHNG 1915.010; MHNG 1915.009; MHNG 1915.008; MHNG 1915.007; MHNG 1915.006; MHNG 1915.005; MHNG 1915.004; MHNG 1915.003; MHNG 1915.002; MHNG 1915.001; MHNG 1914.100; MHNG 1914.099; MHNG 1914.098; MHNG 1914.097; MHNG 1914.096; MHNG 1914.095; MHNG 1914.094; MHNG 1914.093; MHNG 1914.092; MHNG 1914.091; MHNG 1914.090; MHNG 1914.089; MHNG 1914.088; MHNG 1914.087; MHNG 1914.086; MHNG 1914.085; MHNG 1914.084; MHNG 1914.083; MHNG 1914.082; MHNG 1914.081; MHNG 1914.080. Ile Barú, entre Punta Gigante et Bocachica, MHNG 1924.028; MHNG 1924.027; MHNG 1924.026; MHNG 1924.025; MHNG 1924.024; MHNG 1924.023; MHNG 1924.022; MHNG 1924.021; MHNG 1924.020; MHNG 1924.019. Tolú viejo, cueva de Tolu Viejo, MHNG 1902.041; MHNG 1072.095-1073.029; ICN 2774. Boyaca: Santa Ana, cueva orilla carretera, 1750 m, ICN 9107. Caqueta: PNN. Chiribiquete. Sector Suroriental. Río Mesay. Puerto Abeja 0 04' 27" N; - 72²7' 05" W 250 m, IAvH 7168; IAvH 7137; IAvH 7136. Río Mesay, Puerto Abeja, al Suroriente de la Serranía de Chiribiquete, 240 m, ICN 14597. Municipio Montañitas, Vereda Santuario, Finca Ceilán, 335 m ICN 16892-93. Municipio Florencia, cueva Los Guacharos, 540 m, ICN 16894. Cauca: Guapi, Isla Gorgona, ICN 4705. Cauca, Mercaderes, San Joaquín, MHNUC 1692-1694. Cesar: Villanueva, ICN 884. Córdoba: Campo alegre, Grotte de Palmira, MHNG 1902.085. Guainia: Serranía de Naquen, cerro, 450 m ICN 12027-29. Municipio Puerto Inírida, Caño Nabuquén, raudal Yuruparí, RNN Puinawai, en bosque

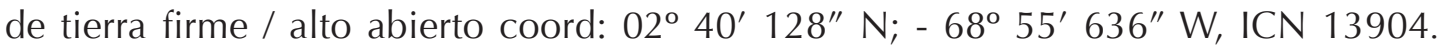
Guaviare: Municipio San José, Vda. La Pizama, sitio Ciudad Perdida, Los Juneles. Reserva Natural Serranía La Lindosa, ICN 16186-87. La Guajira: Uribia, Nazareth, ICN 5483-87; ICN 5555-62; ICN 5807-10. Serranía de Macuira, Cañoo Maporito, \pm 650 m, ICN 8838. Magdalena: Isla Salamanca, ICN 5813. PNN Tayrona, Arrecifes, ICN 7815. PNN Tayrona. Cero Noseve, IAvH 4239. Meta: Acacías, Alrededores de Acacías, ICN 4692-93. Cubarral, Mpio Cubarral, vereda Mesa Redonda, quebrada La Cristalina, 600 m, ICN 14391-92. Extremo sur de la Sierra de La Macarena, ICN 5784-5802. Extremo sur de la Sierra de La Macarena, cueva arriba de la III quebrada, campamento No 1, 235-250 m, ICN 864. Extremo S de la Macarena mts., cueva al NW de Campamento No. 1, ICN 940. Extremo Sur Sierra La Macarena. Campamento No 1, cuevas en escarpa, $\pm 250 \mathrm{~m}, \mathrm{ICN}$ 3074. Extremo sur de la Sierra de La Macarena, alrededores Campamento No 1. segunda cueva, ICN 4659; ICN 4673. Extremo Sur de la Sierra de La Macarena, alrededores Campamento No 1, ICN 4660-63. Extremo 
sur de la Sierra de La Macarena, cuevas escarpa NW del Campamento No 1,300 m. ICN 4664-65. Extremo Sur de la Sierra de La Macarena, margen izquierda $(\mathrm{N})$ del rio Guayabero, tercera quebrada del Campamento No 1, ICN 4666-67. Extremo Sur de la Sierra de La Macarena, cueva al NW del campamento principal, ICN 4668-70; ICN 4672. PNN "La Macarena" Caño Cristales, tributary, E. of Raudal, IAvH 3151; IAvH 2487, IAvH 2087. Extremo Sur de la Sierra de La Macarena, cueva sobre la tercera quebrada al O. del campamento No 1, 235- 250 m. ICN 1760. PNN “La Macarena", upper Caño Cristales, N. Fork, IAvH 2062. PNN La Macarena, Loma de Conejos, NW El Refugio, IAvH 2485; IAvH 2484; IAvH 2483; IAvH 2482; IAvH 2081; IAvH 2077; IAvH 2075; IAvH 2065, IAvH 2042. Puerto López, MHNG 1902.087. Restrepo, grotte Río Guatiquía, MHNG 1900.100; MHNG 1900.099; MHNG 1900.098; MHNG 1900.097; MHNG 1900.096; MHNG 1900.095; MHNG 1900.094; MHNG 1900.093. Villavicencio, MHNG 1924.054; MHNG 1924.053; MHNG 1924.052; MHNG 1924.051; MHNG 1924.050; MHNG 1924.049; MHNG 1922.099; MHNG 1922.098; MHNG 1922.097; MHNG 1922.096; MHNG 1922.095; MHNG 1922.094; MHNG 1922.093; MHNG 1922.092. Villavicencio, Entre Villavicencio et Restrepo, MHNG 1922.091; MHNG 1904.003; MHNG 1904.001-1904.002. Norte De Santander: Municipio Toledo. Rio Negro. Fca. San Isidro. PNN Tama $07^{\circ} 07^{\prime} 22^{\prime \prime} \mathrm{N} ;-2^{\circ} 14^{\prime}$ 42" W 1000 m, IAvH 6692. Santander: Barrancabermeja, La Primavera, selva, ICN 4700. Puente Nacional (5km), Rio Suarez (1900m), MHNG 1902.086. Sucre: Tolu viejo, ICN 5563-75. Putumayo: MHNG 1902.082. Mocoa, eglise de Mocoa, MHNG 1902.081; MHNG 1902.080; MHNG 1902.079; MHNG 1902.078; MHNG 1902.076. Vichada: PNN "El Tuparro" Centro Administrativo, IAvH 3579. Territorio Faunístico "El Tuparro"; E. edge of Cera Rocosa, IAvH 2302; IAvH 2105; IAvH 2088. Valle Del Cauca: Buenaventura 29 km al SE, Qda. Zabaletas, ICN 5877. Vaupes: Sabanas de "Kubiyu", ICN 1932-52. Orilla derecha del Río Guaviare; cerca a la confluencia del Ariari "Cueva de Los Indios", fisuras y cuevas en estratos de arenisca a corta distancia del rio con vegetación, ICN 3440-41. Cerros de la Lindosa 10 km Al Sur de San José del Guaviare, ICN 4582. Cueva del cerro de las pinturas, al lado de la angostura 2, ICN 4671. Mitú; Municipio Mitú, rocas de Urania, a $6 \mathrm{~km}$ aproximadamente de Mitú rio abajo por el Vaupés, ICN 16960. Mitú, finca La Urania, Cerro Chimbe, ICN 3077. Vichada: Parque Nacional Natural El Tuparro, estación Centro Administrativo del INDERENA (CAI), al E del CAI sobre la carretera que conduce a la estación El Tapón del parque 05 18' 99" N; - 670 53' 40.6" W, ICN 13940.

Peropteryx pallidoptera. Caquetá: Montañita, Vereda Las Juntas, Hacienda Las

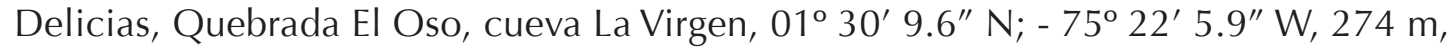
ICN 21468-69. Meta: Municipio de Puerto Gaitán, en inmediaciones del sector del

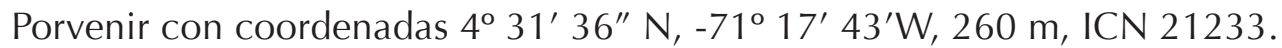

Rhynchonycteris naso. Amazonas: Caserío de Araracuara, ICN 8503. Caserío "Huiru" 15 km debajo de La Chorrera R. Igará-Paraná, IAvH 695. Tarapacá, Corregimiento Tarapacá, Río Putumayo, sitio El Porvenir, ICN 15377. Antioquia: Zaragoza 25 km S 22 W Zaragoza (La Tirana) 410m, IAvH 959; IAvH 2030. Bolivar: Tolú, bajo el puente del arroyo Guayaní, 2 km al N de Tolú, ICN 2773. Boyacá: Municipio Puerto Boyacá, km 30 vía Puerto Romero - El Ocal, ICN 14803-03. Caldas: Municipio Samaná, Hda. Lindaraja. Aguas debajo de la presa Miel I (CHEC), ICN 14276. Cauca: Montañitas, 
cercanías escuela Palma Azul, quebrada Coconuco, 350 m, ICN 11282-94. Rio Mesay, Puerto Abeja, (Rebalse) al Suroriente de la Serranía de Chiribiquete, 240 m, ICN 14613. Rio Mesay, Chorro de Mazaca, ca. 240 m ICN 14697-98. Munchique, MHNG 1907 0.95 MHNG 1097 0.94. Casanare: Vereda Los Chochos, Finca Las Plumas, ICN 19264. Cesar: Gamarra, Corregimiento Botega Central, ICN 12625-26. Chocó: Municipio Riosucio, Vda Cristales PNN Katios, IAvH 4906-07. Riosucio, Vereda Cristales, parque Nacional Natural Los Katios, ICN 6906-07; ICN 6910. Córdoba: Lorica; Estación Piscícola de la Corporación Autónoma Regional de los Valles del Sinú y del San Jorge (CVS), ICN 17205-06. Meta: PNN La Macarena, Cabaña Duda, IAvH 2025; PNN La Macarena, Alto caño Cristales. Taken in net over dry stream bid, IAvH 2480; Monteria: Corregimiento Tres Piedras, Caserío Maracayo, sitio El Lúcido, ICN 17207-09. Corregimiento Nariño, Vereda Ceiba Pareja, Ciénaga Pantano Bonito, ICN 17210-12. Guainía: Municipio Puerto Inírida, caño Nabuquen, raudal Yurupari, RNN Puinawai, en bosque de tierra firme / alto abierto coord: $02^{\circ} 40^{\prime} 128^{\prime \prime} \mathrm{N}$; - $68^{\circ} 55^{\prime}$ 636" W, ICN 13905. Pto. Inírida, caño Caimán, resguardo El Remanso $3^{\circ}$ 39' 16" N; - $67^{\circ} 57^{\prime}$ 8" W, 80 m, ICN 14938. Magdalena: "Santa Marta", Colonia Agrícola de Caracolito, 400 m, ICN 873. Santa Marta, PNN. Tayrona, Los Naranjos, 7816. Municipio Sitinuevo, Santuario de Fauna y Flora Ciénaga Grande de Sta. Marta, Caño El Cojo, ICN 15411-12. Municipio Sitinuevo, Santuario de Fauna y Flora Ciénaga Grande de Sta. Marta, Caño El Cojo, El Juncal, ICN 15413-19. Municipio Remolino, Santuario de Fauna y Flora Ciénaga Grande de Sta. Marta, Ciénaga de La Aguja, Isla de Ochoa. ICN 16129-30. Meta: Caño Navajas, ICN 2026. Caño Yurimena, ICN 2024. Acacías, Apiai, ICN 2025. Extremo Sur de la Sierra de La Macarena, margen derecha del Rio Guayabero, 100 m, arriba de las bocas del Caño Lozada, en raiz tabloide de una "ceiba" con bastante exposición de luz, apenas sombreada, contra el rio, ICN 2129-31. Extremo Sur de la Sierra de La Macarena, Campamento No 1, cueva en la escarpa inmediata al campamento. Orilla del rio, ICN 3980-81. Puerto López, Vereda Menegua, Finca Lagunazo, ICN 9465. Cumaral, La Y, puente sobre vía Paratebueno, Medina - Cuamaral \pm 3 km NO, 580 m, ICN 11354. Cumaral, Vereda Cepera, 5 km NE de Cumaral, La Ye, Quebrada Seca, 500 m. ICN 11355-60. Municipio de Mesetas, Vereda San Isidro, cuenca media del Río Duda, margen izquierda, $\pm 420 \mathrm{~m}$, ICN 11525. Municipio de Restrepo, Vereda Caney Alto, centro Cread (Unillanos), en bosque detrás de las instalaciones, Vereda El Palmar, vía a San Nicolás, km 20 caño Caibe, 400 m, ICN 13901-02. Corregimiento Pachiaquiaro, Vereda Yacumal, ICN 19124; ICN 19133. Putumayo: Municipio de Puerto Leguizamo, Vereda El Guadual, Finca de Pablo Aguirre, Hda. Hernandez. R. Caucaya, PNN La Paya, ICN 13761-62. Santander: Puerto Parra, Vereda India Baja, Corregimiento Campo Capote, ICN $17757-$ 58; ICN 17760; ICN 18795. Sucre: Municipio San Marcos, Vereda La Florida, Ciénaga Gamboa, Granja Cocodrilia, 34 m, 08 35' 49.9" N 75 08' 31.2" W, ICN 1743436. Valle Del Cauca: Buenaventura 29 km SE, Rio Zabaletas MHNG 1912 0.25; Vichada: PNN El Tuparro 2 km SE del Centro Administrativo. Rio Tomo IAvH 2481. Buenaventura, Quebrada Zabaletas, aproximadamente $10 \mathrm{~km} \mathrm{~N}$ del sitio de Zabaletas, ICN 5870. Vaupes: Sabanas del Cubiyú, ICN 792. Mitú, a orillas del Río Cuduiari, 2 m. ICN 13110-11. Vichada: Parque Nacional El Tuparro. Alrededores del Centro Administrativo, ICN 12385-86. 
Saccopteryx antioquensis. We did not have chance to check the holotype of $S$. antioquenisis.

Saccopteryx bilineata. Colombia: MHNG 1909.043; MHNG 1909.042. Amazonas: Caserío de Araracuara, ICN 8502. Caserío "Kuirú" 15 km debajo de la Chorrera, R. Igará-Paraná, IAvH 693. Antioquia: Río Negro, Urabá, ICN 3259-69. Cocorná, Vereda San Pablo, Quebrada San Pablo, 810 m, ICN 9755. San Luis, Vereda San Pablo, Quebrada San Antonio, 810 m, ICN 9756. Zaragoza 23 km S 22 W Zaragoza. Alt: 410 m, IAvH 1391. Caldas: Municipio Samaná, corregimiento Norcasia, alrededores campamento CHEC, 650 m, ICN 10800-03. Samaná, Corregimiento de Norcasia, Vereda La Pradera, Campamento de la (CHEC) Corporación Hidroeléctrica de Caldas, Estación La Miel I, 610 m, ICN 12487. Municipio Samaná, Vereda La Miel, cercaníaa de campamento Tasajos, margen derecha Río La Miel, ICN 14305. Caqueta: PNN Chiribiquete. Sector Sur Oriental. Rio Mesay. Puerto Abeja $0^{\circ} 04^{\prime} 27^{\prime \prime} \mathrm{N} ;-72^{\circ} 27^{\prime} 05^{\prime \prime}$ W 250 m, IAvH 7133; IAvH 7203. Guainia: Rio Guaviare, Caserío Cuayaré, margen derecha del Rio Inírida, IAvH 5235. Río Mesay, Puerto Abeja, al suroriente de la Serranía de Chiribiquete, 240 m, ICN 14614-15. Río Mesay, Chorro de Mazaca, ca 240 m, ICN 14699. Cauca: Municipio Guapi, isla Gorgona, dentro del antiguo penal, 0 m, ICN 10171-72. Cesar: Villanueva, ICN 886. Chocó: Pacurita, CMCH 001248; CMCH 00994; CMCH 00939; CMCH 00895; Salero CMCH 00573. Mpio Riosucio, "PNN Katios" , Cristales-Río Cacarica; Margen izquierda, IAvH 3153. Vereda La Santata "PNN Katios" , IAvH 4904. Riosucio, Vereda Sautata, parque Nacional Natural Los Katíos, ICN 6908; ICN 7602. Córdoba: Corregimiento El Porro, Vereda La Corosa, Ciénaga El Porro, Hacienda La Vaqueta, ICN 17213-14. Guaviare: Municipio San José de Guaviare, Vda. Bocas de Agua Bonita, sitio de Bocas de Agua Bonita, ICN 16188. Huila: Gigante, Vda. Espinal, Puerto Seco, 730 m ICN 7613-14. Municipio Baraya, sitio El Cruce, finca Las Delicias, 750 m, ICN 13620. La Guajira: Valle del Cerrejón, Arroyo Bruno, ICN 18613. Magdalena: Bonda, Río Jordán (7400;11¹8’), MHNG 1900.090; MHNG 1900.09; MHNG 1900.092; MHNG 1900.087; MHNG 1900.088; MHNG 1900.089; MHNG 1900.085; MHNG 1900.084; MHNG 1900.086. Isla Salamanca. ICN 5811-12. Santa Marta, PNN. Tayrona, Arrecifes, ICN 7817. Santa Marta, Parque Tayrona, Cañaveral, Quebrada Mason. ICN 3640-41. Santa Marta, PNN. Tayrona, Cañaveral ICN7818; ICN 15410. Santa Marta, PNN. Tayrona, Cinto, ICN 7819. Santa Marta, PNN. Tayrona, El Cedro ICN 8991-92. PNN Tayrona, El Cedro. II Exp Botánica, IAvH 4202. Putumayo: MHNG 1923.070; MHNG 1923.068; MHNG 1923.071; MHNG 1923.072; MHNG 1923.069; MHNG 1923.067; MHNG 1923.066; MHNG 1923.065. Orito I, Campamento Texaco (altura: 330 m) 058`59" 2 N; 21, 31'20“4 W de origen Bogotá, MHNG 1902.066; MHNG 1902.065; MHNG 1902.069; MHNG 1902.064; MHNG 1902.068; MHNG 1902.067. Municipio Remolino, Santuario de Fauna y Flora Ciénaga Grande de Sta. Marta, Caño Palenque, Finca "El Presidio" , ICN 15409. Meta: Carimagua, estación experimental ICA, ICN 5871-73. Extremo S de la Sierra de La Macarena, Campamento No 1 cueva en la escarpa inmediata al campamento, ICN 4038-42. Puerto López, vereda Menegua, Finca Lagunazo, 250 m, ICN 9466-67. Municipio San Juan de Arama, parte norte Serranía La Macarena, caño Guamalito, \pm 500 m, ICN 10222-23. Municipio San Juan de Arama, parte norte Serranía La Macarena, caño La Curia, \pm 500 m. ICN, 10221. Municipio de 
Mesetas, Vereda San Isidro, cuenca media del Río Duda, margen izquierda, +-/ 420 m, ICN 11526. Villavicencio, ICN 861. Norte De Santander: Cúcuta, cerca a Tibú, Campamento No 2, margen izquierda del Río Sardinata, ICN 4594. Sucre: Tolú, Hda. La Estancia, Sector "El Bobo", en la comba de una Ceiba punctata, Pastizal El Bolsillo, IAvH 3152. Valle Del Cauca: Bajo Río Calima, ICN 3984. Cartago (3km E), MHNG 1906.016. Guadalajara, 10 a 12 km de Buga, carretera via represa Calima, Finca Chimbilaco, ICN 5299-01. Tuluá, Jardín Botánico Mateguadua, 1,050 m, ICN 13180. Vichada: Laguna Danta, Río Vichada, 150 m, ICN 4953. Parque Nacional El Tuparro. Alrededores del Centro Administrativo, ICN 12684. Parque Nacional Natural El Tuparro, estación Centro Administrativo del INDERENA, cerros a $500 \mathrm{~m}$ al $\mathrm{N}$ del CAI 05 21' 17.0" N; - 670 51' 40.6" W, ICN 13941. Territorio Faunístico "El Tuparro"; Centro Administrativo, IAvH 2063.

Saccopteryx canescens. Boyaca: Los Trompillos, MHNG 1912.035; CASANARE: Paz de Ariporo, Corregimiento La Hermosa, finca Nicaragua. B. inundable, IAvH 8104. Magdalena: Bonda, MHNG 1073.34; MHNG 1073.32; MHNG 1073.33; MHNG 1073.35; MHNG 1073.36. PNN Isla de Salamanca Los Cocos, Sendero IAVH 5487; IAVH 5486; META: PNN La Macarena, 80 m N. del Campamento Isawa, Rio Duda, $\mathrm{IAvH}$ 2277. Trinidad, Vereda Los Chochos, Finca Las Plumas, ICN 19265. Vereda El Banco de La Cañada, Finca La Palmita, ICN 19266-67. La Guajira: Río Ranchería, sector Calaguala, ICN 18614. Valle del Cerrejón, Arroyo Bruno, 18615. Magdalena: Santa Marta, PNN. Tayrona, Gairaca, ICN 7820-21. PNN Tayrona, Los Naranjos, ICN 7982. Meta: Restrepo, Vereda Caney Alto, ICN 10097. Sucre: Municipio San Marcos, Vereda La Florida, Ciénaga Gamboa, Granja Cocodrilia, 34 m.s.n.m., $08^{\circ}$ 35' 49.9" N 75 08' 31.2" W, ICN 17437. Vichada: Parque Nacional Natural El Tuparro, estación Centro Administrativo del INDERENA (CAI), al E del CAI sobre la carretera que conduce a la estación El Tapón del parque, ICN 13942.

Saccopteryx leptura. Amazonas: Corregimiento Tarapacá, Río Putumayo, sitio El Porvenir, ICN 15378. Antioquia: Municipio San Luis, Corregimiento El Prodigio, Vereda Las Confusas, Finca Corinto, 555 m, ICN 13301. Bolivar: Municipio Cartagena, Archipielago de San Bernardo, isla Mucura, Finca Dablandia, ICN 16152-53. Cauca: Guapi, Isla Gorgona, UV 2 061, UV3265-66, UV 3277-83, UV 3294-95. Guapi, Río Guapi, Caserío El Naranjo, UV 10148. Piamonte, Puerto Bello, UV 11381. Isla Gorgona, ICN 4704. Chocó: Bahía Solano, El Valle, ICN 5875. Pacurita, CMCH 001334; CMCH 1337; CMCH 1315; CMCH 1317; CMCH 1141-42; 948; 956; Rio Sucio IAvH 4905. Riosucio, Vereda Sautatá, Parque Nacional Natural Los Katíos, ICN 6909. Córdoba: Ayapel, Ciénaga de Ayapel, Caserío Playa Blanca, Finca Quiebrahacha, ICN 17215. Guainia: Serranía de Naquén, cerro, 450 m, ICN 12030. La Guajira: Albania, Ranchería sector Calaguala, ICN 18616-17. Uribia, Nazareth, ICN 5488-90. Maicao, Vda. Bruno, campamento Los Montes de Hernán, $230 \mathrm{~m} 11^{\circ} 09^{\prime} 0.58^{\prime \prime} \mathrm{N}$; - 72 $33^{\circ}$ 23.7" W, ICN 14948-49. Magdalena: PNN. Isla de Salamanca, Los Cocos, IAvH 5485; Sucre: Tolú, Hacienda Estanzuela, Sector "El Bobo" Bosque aledaño a casa IAvH 3154. Meta: Municipio San Juan de Arama. Parte Norte de la Serranía La Macarena. Caño Guamalito, 550 m, ICN 12043. Tolima: Melgar, orillas del Río Sumapaz, 430 m, ICN 4073. Municipio Lérida, Quebrada El Sitio, 480 m, ICN 17652. Valle Del Cauca: 
Cali, Ciudad Universitaria, ICN 5876. Tulua, Jardín Botánico Mateguadua, 1,050 m, ICN 1318. Vaupes: Mitú, en el Colegio José E. Rivera, ICN 16962.

\section{Appendix 2}

Records obtained from museum databases, specimens reviewed and scientific literature $(1,165)$, used as input in the generation of the models: American Museum of Natural History (AMNH; $n=216$ ); British Museum of Natural History (BM; $n=1$ selected records reported in the literature); $(\mathrm{IAvH} ; n=3$ selected records reported in literature); Instituto de Ciencias Naturales, Universidad Nacional de Colombia (ICN; $n$ = 449); Field Museum of Natural History (FMNH; $n=55)$; Kansas University (KU; $n=$ 1 selected record reported in the literature); Museo de Historia Natural Universidad de Caldas (MHNUCa; $n=1$ selected record reported in the literature); Museo de Historia Natural Universidad de la Universidad del Cauca (MHNUC; $n=4$ ); Muséum d' Histoire Naturelle de Genève (MHNG; $n=147$ ); Museo Javeriano de Historia Natural "Lorenzo Uribe Uribe" (MUJ; $n=10$ selected records reported in Pérez-Torres et al. 2007); National Museum Smithsonian Institution (USNM; $n=354$ ); Museum of Vertebrate Zoology (MVZ; $n=60$ ); Royal Ontario Museum (ROM; $n=3$ selected records reported in the literature); Texas Tech University Museum (TTU; $n=1$ ); University of Washington $(U V ; n=16)$; Zoological Museum (UWZM; $n=1)$. 
Models of potential distribution created for the 16 emballonurid species present in Colombia.

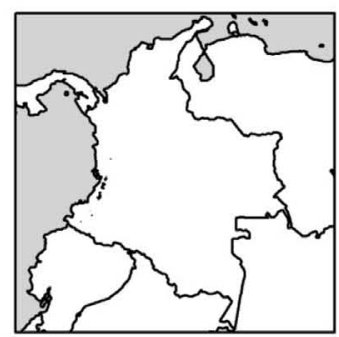

Balantiopteryx infusca

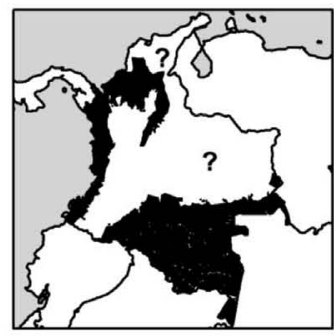

Diclidurus albus

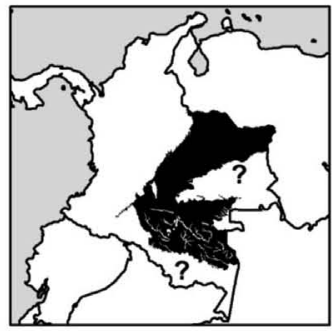

Peropteryx leucoptera

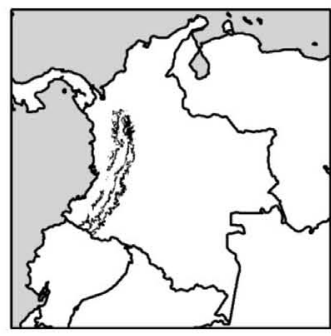

Saccopteryx antioquensis Saccopteryx bilineata

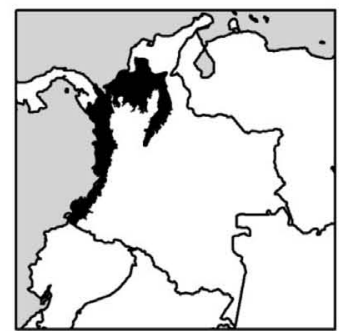

Centronycteris centralis

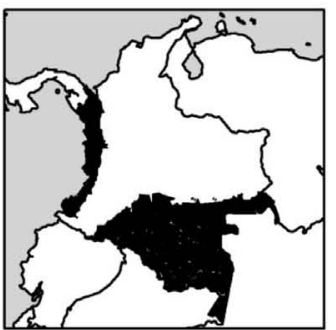

Diclidurus ingens

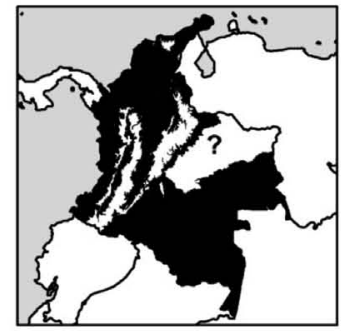

Peropteryx macrotis

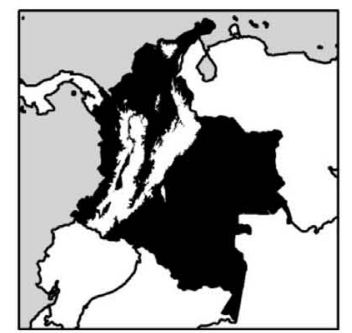

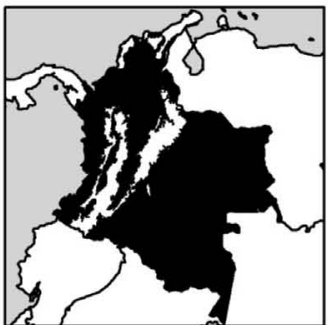

Cormura brevirostris

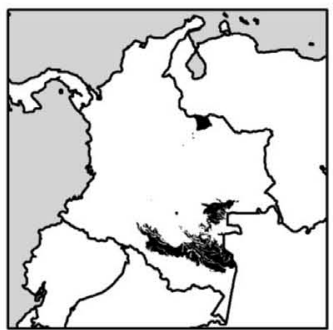

Diclidurus scutatus

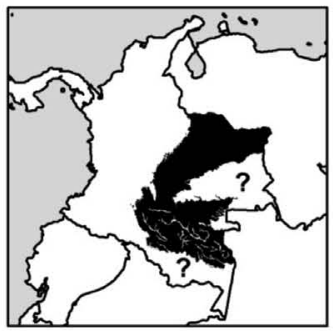

Peropteryx pallidoptera

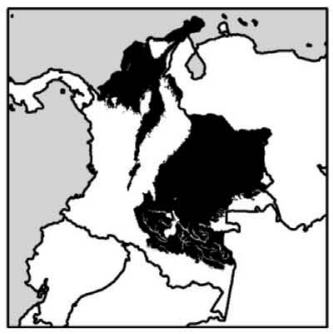

Saccopteryx canescens

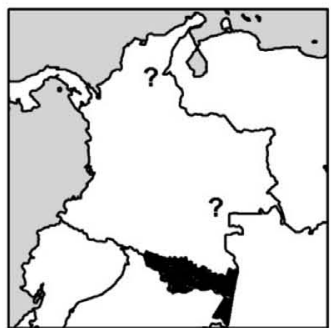

Cyttarops alecto

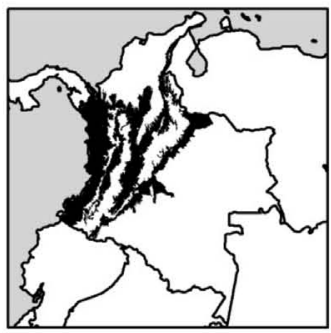

Peropteryx kappleri

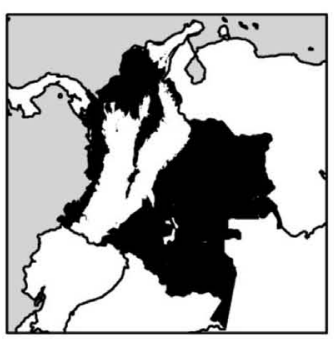

Rhynchonycteris naso

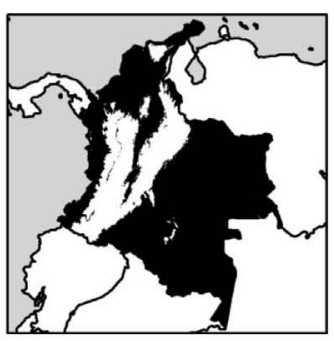

Saccopteryx leptura 


\section{Appendix 4}

Confirmed Colombian emballonurid species presence absence matrix by natural region. Natural Regions in Colombia: Amazon (amz); Andean (and); Caribbean (car); Orinoquia (ori); Pacific (pac).

\begin{tabular}{lccccc}
\hline & \multicolumn{5}{c}{ Natural Region } \\
\cline { 2 - 5 } Species & amz & and & car & ori & pac \\
\hline Balantiopteryx infusca & 0 & 0 & 0 & 0 & 1 \\
Centronycteris centralis & 0 & 1 & 1 & 0 & 0 \\
Cormura brevirostris & 1 & 1 & 1 & 0 & 1 \\
Cyttarops alecto & 1 & 0 & 0 & 0 & 0 \\
Diclidurus albus & 1 & 1 & 1 & 0 & 1 \\
Diclidurus ingens & 1 & 0 & 0 & 0 & 1 \\
Diclidurus scutatus & 1 & 0 & 0 & 0 & 0 \\
Peropteryx kappleri & 1 & 0 & 1 & 0 & 1 \\
Peropteryx leucoptera & 0 & 0 & 0 & 1 & 0 \\
Peropteryx macrotis & 1 & 1 & 1 & 1 & 1 \\
Peropteryx pallidoptera & 1 & 0 & 0 & 1 & 0 \\
Rhynchonycteris naso & 1 & 1 & 1 & 1 & 1 \\
Saccopteryx antioquensis & 0 & 1 & 0 & 0 & 0 \\
Saccopteryx bilineata & 1 & 1 & 1 & 1 & 1 \\
Saccopteryx canescens & 1 & 1 & 1 & 1 & 0 \\
Saccopteryx leptura & 1 & 1 & 1 & 1 & 1 \\
Total spp. & 12 & 9 & 9 & 7 & 9 \\
\hline Unique species & 2 & 1 & 0 & 1 & 1 \\
\hline
\end{tabular}


